\title{
Genealogical Position of Ugaritic: the Lexical Dimension. Lexical Isoglosses between Ugaritic and other Semitic Languages.
Conclusions
}

\author{
Leonid Kogan ** \\ Russian State University for the Humanities, Moscow
}

This article is the concluding part of a series of publications by the author dealing with the lexical factor in the genealogical subgrouping of Semitic. In the focus of the discussion are the exclusive lexical isoglosses between Ugaritic and Semitic languages other than Canaanite: Arabic, Aramaic and Akkadian. In both former cases, such isoglosses are few in number, which almost certainly excludes any particularly close association between Ugaritic and Arabic or Aramaic. Conversely, UgariticAkkadian isoglosses are comparatively numerous, which can be explained in several possible ways. In the concluding section, the Canaanite affiliation of Ugaritic as reflected in the basic vocabulary is reaffirmed, with a special emphasis on the hypothetic Ugaritic-Phoenician connection.

KeYwords: Lexical Isoglosses; Basic Vocabulary; Ugaritic; Arabic; Aramaic; Akkadian; Hebrew; Phoenician; Genealogical Classification of Semitic.

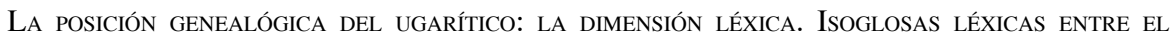
UGARÍTICO Y OTRAS LENGUAS SEMÍtICAS. CONCLUSIONES.- El presente artículo concluye una serie de publicaciones dedicadas al factor léxico en la clasificación genealógica de las lenguas semíticas. En el centro de la discusión están las isoglosas léxicas que reúnen el ugarítico con otras lenguas semíticas no cananeas: el árabe, el arameo y el acadio. En los dos primeros casos, tales isoglosas son poco numerosas, el que prácticamente excluye la posibilidad de una relación genealógica más o menos estrecha entre el ugarítico y el árabe o el arameo. En cambio, las relativamente numerosas coincidencias entre el ugarítico y el acadio parecen remarcables y necesitan una explicación diacrónica. En la sección final del artículo, se reafirma la afiliación cananea de la lengua ugarítica, enfatizando el probable nexo especial entre el ugarítico y el fenicio.

PALABRAS CLAVE: Isoglosas léxicas; vocabulario básico; ugarítico; árabe; arameo; acadio; hebreo; fenicio; clasificación genealógica del semítico.

* The article was written in the framework of the projects 08-04-00465a (РГНФ/RFH) and 0906-00153-a (РФФИ/RFBR). I am grateful to these institutions for their financial support.

**1kog@rggu.ru 
The present contribution continues the diachronic analysis of the Ugaritic vocabulary undertaken in the previous issue of Sefarad, now focusing on possible exclusive lexical isoglosses between Ugaritic and non-Canaanite Semitic languages: Arabic, Aramaic and Akkadian. ${ }^{1}$ Presentation of the evidence will be followed by a general discussion and some preliminary conclusions.

\section{Exclusive isoglosses between Ugaritic and other Semitic languages}

It goes without saying that a correct evaluation of the exclusive isoglosses between Ugaritic and Canaanite can only be achieved by comparison with exclusive isoglosses shared by Ugaritic and other Semitic languages. Three groups of such isoglosses have been detected in the course of the present investigation - Ugaritic-Arabic, Ugaritic-Aramaic and Ugaritic-Akkadian.

\subsection{Ugaritic-Arabic}

Exclusive lexical isoglosses between Ugaritic and Arabic occupy a special place in the history of Ugaritic lexicography because of the extraordinary richness of the Arabic vocabulary. Incidentally, these lexical features have often been adduced as a proof of a special genealogical proximity between Ugaritic and Arabic. Much of the relevant material is dealt with in a special monograph (Renfroe 1992) - something which exclusive lexical isoglosses uniting Ugaritic with either Hebrew or Akkadian have never received.

Renfroe's study provides a solid background for this segment of our investigation, but numerous points of disagreement in both methodology and concrete etymological decisions have compelled me to undertake an independent scrutiny of the pertinent lexical evidence. On the wake of Renfroe, the results are presented in two separate subsections. Isoglosses which are both truly exclusive and philologically reliable are listed in the first subsection. The second subsection presents a selection of isoglosses which, for various reasons, have been considered unreliable or not compelling. I will thus attempt to demonstrate - once again! ${ }^{2}$ — how many of the allegedly exclusive lexical isoglosses between Ugaritic and Arabic do not withstand critical scrutiny.

\footnotetext{
${ }^{1}$ Bibliographic references and abbreviations can be found at the end of this article.

${ }^{2}$ To be sure, at this very point Renfroe's results are already quite persuasive.
} 


\subsubsection{Probable}

In Renfroe 1992:11-74, twenty-four exclusive lexical isoglosses between Ugaritic and Arabic are acknowledged as probable. Many entries from this selection are indeed reliable, so that much of what I included in the present subsection has been already recognized by Renfroe. ${ }^{3}$ At the same time, quite a number of isoglosses considered reliable by Renfroe have been omitted presently in view of serious philological and/or etymological difficulties. ${ }^{4}$ As a result, the number of exclusive isoglosses between Ugaritic and Arabic has decreased from 24 to 18.

1. 'ušn 'present, gift' (DUL 118).

- Hapax Legomenon in 1.14 III 31-32:'udm ytnt! 'il w'ušn 'ab 'adm ' udm is a gift of ' $i l$ and a present of the father of mankind'.

- Arb. 'ws 'to offer a present', 'aws- 'gift' (LA 6 20).

$\boldsymbol{\nabla}$ Ugr.-Arb. * 'wš 'to grant, to offer a gift' has no cognates elsewhere in Semitic and may be considered an exclusive isogloss (cf. Renfroe 1992:16).

2. ' 'k k 'a destructive one' (DUL 177).

- Attested twice as a divine epithet, the meaning 'ripper' is probable because of the parallelism with 'aklm 'devourers': hl ld 'aklm tbrkk $w$ ld ' $\mathrm{kkm}$ 'writhe and bear the devourers, kneel and bear the rippers' (1.12 II 25-27), wn ymry 'aklm w ymța $\mathrm{kkm}$ 'that he might reach the devourers and meet the rippers' (1.12 I 36-37).

\footnotetext{
${ }^{3}$ Additions are seven: $p$ 'id 'heart', $b s ̦ r$ 'to watch', $m z$ ' 'to tear', rḳs 'to jump', ltpn 'benevolent', gngn/ggn 'interior' and šbm 'to muzzle'. The former four isoglosses are just missing from Renfroe's book. The latter three are rejected by Renfroe as non-exclusive, which is fully or partly unjustified.

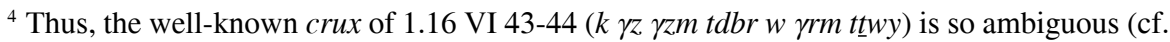
Pardee's recent evaluation in 1997:342) that I prefer to leave out of consideration three otherwise plausible exclusive isoglosses accepted by Renfroe: Ugr. $\gamma z$ — Arb. $\gamma z w$ 'to invade' (1992:39-41), Ugr. $\gamma r m$ - Arb. $\gamma w r$ 'to plunder' (1992:37) and Ugr. $t \underline{t w y}$ - Arb. $\underline{t w y}$ 'to be idle' (1992:68-69). The same applies to such highly problematic passages as $k$ t $\gamma \underline{d}$ 'arz $b$ ymnh in 1.4 VII 41 (Ugr. $t \gamma \underline{d}$ - Arb. $\gamma \underline{d} y$ 'to hasten, to speed', Renfroe 1992:31-34, cf. Pardee 1997:263, DUL 317-318), tk.ln $b$ gbl šntk $b$ hpnk $w t^{\prime} n$ in 1.16 VI 57-58 (Ugr. hpn - Arb. hff 'to surround, to encompass', Renfroe 1992:49-52, cf. Pardee 1997:343, DUL 366), 'adr b $\gamma l$ ' 'il knm in 1.7 VI 23 (Ugr. $\gamma l-$ Arb. $\gamma 1$ - 'thicket', RenFroe 1992:34-36, cf. PARDEe 1997:347, DUL 318). Sabaic and other ESA languages are often tacitly assumed to be the same as "Arabic" in Renfroe's study, which is by no means warranted (cf. RENFROE 1992:2). Ugaritic-Arabic isoglosses shared by ESA are, therefore, not to be considered exclusive. This objection applies to the multiplicative enclitic -id as well as to ' $d b$ 'to put in order, to prepare', ' $n n$ 'assistant' and $h t \underline{t} t$ 'fate, lot'.

${ }^{5}$ For the presence of $*$ ' $w s ̌$ in Hebrew onomastics and its methodological significance v. Kogan 2006b (especially p. 243).
} 
- Arb. ' $q q$ 'to split, to rip, to cut' (Lane 2095).

$\nabla$ The exclusive nature of the Ugr.-Arb. isogloss (acknowledged in Renfroe 1992:24-26) is to some extent undermined by Tgr. 'akkä 'to cut, to wound, to furrow' (WTS 467), which, however, may be an Arabic loanword in view of the lack of cognates elsewhere in Ethiopian Semitic.

3. $\boldsymbol{t} \boldsymbol{k}$ 'to tie, to fasten, to bind' (DUL 191).

- Attested in stereotype descriptions of heads fastened to the belt: 'tkt r'išt l bmth šnst kpt b ḥbšh 'she attached heads to her back, bound hands to her gird' (1.3 II 11-13). ${ }^{6}$

- Arb. 'tk 'to stick (intrans.)' (Lane 1948).

$\boldsymbol{\nabla}$ Ugr.-Arb. * 'tk 'to stick, to attach' is an exclusive isogloss (Renfroe 1992:26-29).

\section{4. bșr 'to watch' (DUL 241).}

- The most reliable attestation of this verb is 1.18 IV 30-31: Th nšrm trhpn ybșr ḥbl d'iy $[\mathrm{m}]$ 'vultures soar above him, a band of hawks is watching'. ' As persuasively argued by Pardee (2000:669), $m l k m$ tbșrn in 1.163:4 is to be understood as 'kings will watch one another'. ${ }^{8}$ Conversely, $t b s ̦ r$ in 6.24:1 remains highly problematic (v. Singer 1999:703-704; DUL's translation 'examination' is hardly more than a conjecture).

- Arb. bṣr 'to see' (Lane 210).

$\nabla$ Ugr.-Arb. * $b s ̣ r$ 'to see' is an exclusive isogloss.

5. gngn, ggn 'insides' (DUL 296, 300).

- $\quad$ Attested in 1.16 VI 26 ( $w$ ywsrnn ggnh 'and his inner self instruct him') and 1.4 VII 47-49 (ykrr'a mt b npšh ystrn ydd b gngnh). ${ }^{10}$

${ }^{6}$ The adjective ' $t k$ 'anchored, moored' postulated in DUL 191 for 4.421:4-5 is unreliable because of the damaged context.

${ }^{7}$ Or: ‘is being seen'?

${ }^{8}$ Pardee's Akkadian parallels involving națālu can probably be supplemented by those with amāru N (e. g. šarrānu ina puhrim innammarū in YOS 1033 II 30), cf. CAD A 27.

${ }^{9}$ Mhr. habṣáwr 'to see well' (ML 55), Jib. ebșér id. (JL 29) are likely borrowed from Arabic. An etymological relationship between Arb. $b s ̦ r$ 'to see' and Hbr. bäsärr 'gold ore' (HALOT 149) advocated in RUNDGREN 1963 is at best conjectural.

${ }^{10}$ The syntax of the latter passage makes it difficult for a coherent translation, cf. PARDEE 1997:263, PARKER 1997:137, 172, TROPPER 2000:523. 
- Arb. ̌̌anān- 'interior, heart' (Lane 403).

$\boldsymbol{\nabla}$ Possible cognates to Ugr.-Arb. $* g \mathrm{~V} n \mathrm{Vn}$ - 'heart, interior' dealt with in SED I No. 83 are rather unreliable, so it is preferable to treat this isogloss as exclusive. There is hardly any justification for its rejection by Renfroe (1992:10), whose comparison between Ugr. $g(n) g n$ and Hbr. gargarōt 'throat' (let alone Akk. gagguritu, most probably non-existent) is patently wrong (cf. SED I No. 102).

\section{6. $\boldsymbol{\gamma d d}$ 'to swell' (DUL 317).}

- Hapax Legomenon in 1.3 II 25-27: t $\quad$ dd kbdh b șhk yml'u lbh b šmht kbd ' $n t$ tšyt 'her liver swells with laughter, her heart fills with joy, ' $n t$ 's liver with triumph'.

- Arb. $\gamma d d \mathrm{IV}$ 'to be swollen because of anger', $\gamma u d d a t-$ 'ganglion, bubo' (Lane 2231).

$\nabla$ Ugr.-Arb. * $\gamma d d$ 'to swell' is an exclusive isogloss (Renfroe 1992:3031), provided that MSA parallels like Mhr. yáttad 'to be seized by the throat', yaddet 'influenza' (ML 132), Jib. yedd 'to throttle', yaddét 'choking feeling' (JL 83) are Arabisms.

7. $\boldsymbol{h d y}$ 'to lacerate oneself' (DUL 336).

- Hapax Legomenon in 1.5 VI 19-20: yhdy lhm $w$ dḳn yțlt kn $d r$ ' $h$ 'he lacerated his cheeks and beard, he harrowed his upper arms '.

- Arb. $h \underline{d} w$ 'to cut with a sword' (LA 15 420).

$\nabla$ Ugr.-Arb. * $h \underline{d} w$ 'to cut' as an exclusive isogloss is correctly recognized in Renfroe $1992: 45-48 .{ }^{1 '}$

8. ltpn 'benevolent' (DUL 507).

- $\quad$ Attested as an epithet of 'il, notably in the combination ltpn 'il $d p^{\prime}$ 'id. The meaning of $l t p n$ can only be ascertained through etymological comparison with Arb. ltf (v. extensively Tropper-Hayajneh 2003). L 698). ${ }^{12}$

Arb. ltf 'to be firendly, kind, considerate, indulgent, merciful' (WKAS

\footnotetext{
${ }^{11}$ Comparison between Ugr. $h d y$ and Gez. tahadya 'to be burned through heat, to be dissolved by being cooked too much' mentioned in CDG 215 is semantically unattractive.

${ }^{12}$ For a detailed discussion of the complex meaning of the Arabic root v. TROPPER-HayajneH 2003:164-171.
} 
V The origin of Ugr.-Arb. *ltp is obscure as no further Semitic parallels seem to be attested.

9. $\boldsymbol{m} \boldsymbol{\gamma d}$ 'food, provisions' (DUL 532).

- Hapax Legomenon in 1.14 II 27-31, meaning reliably established from

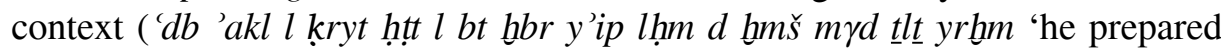
food from the barns, wheat from the storehouse, he baked bread for five months, provisions for three months').

- Arb. $\gamma \underline{d} w, \gamma \underline{d} y$ 'to feed, to nourish' (Lane 2236).

> There is no cognate for Ugr.-Arb. $\gamma \underline{d} w$ 'to feed'. The exclusive nature of this isogloss is correctly recognized in Renfroe 1992:60-61.

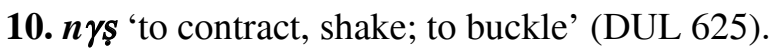

- Attested in the descriptions of buckling bodies of gods (v. No. 51 in section 1).

- Arb. $n \gamma d$ 'to be in motion, convulsion; to totter' (Lane 2818).

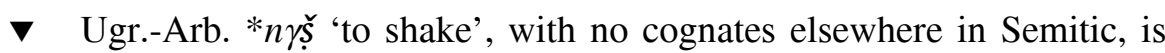
correctly recognized as an exclusive isogloss in Renfroe 1992:62-64.

11. p'id 'heart' (DUL 658).

- Attested exclusively in the combination 'il $d p^{\prime}$ 'id (Tropper-Hayajneh 2003), the meaning 'heart' is established on etymological grounds only.

- Arb. fu'ād- 'heart' (Lane 2323). ${ }^{14}$

$\nabla$ Ugr.-Arb. ${ }^{*} p \mathrm{~V}^{\prime} d$ - 'heart' has no reliable Semitic cognates (cf. SED I No. 205).

12. $\boldsymbol{m r} \boldsymbol{\gamma} \underline{\text { ' }}$ suckling' (DUL 574).

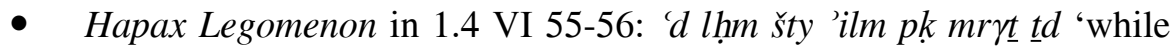
gods are eating, drinking, consuming sucklings'.

- Arb. $r \gamma \underline{t}$ 'to suck' (Lane 1112).

${ }^{13}$ Contra Renfroe 1992:127, Tgr. lätfä 'to be mild, gentle' (WTS 50) has no bearing on the exclusive nature of the Arabic-Ugaritic isogloss since the Tigre verb is obviously borrowed from Arabic. The same is true of similar Arabisms in a variety of other Semitic languages, such as Harari, MSA and modern Hebrew (rightly acknowledged in TropPER-HAYAJNEH 2003:171). 175.

${ }^{14}$ A detailed semantic analysis of Arb. $f u ' a \bar{d}$ - can be found in Tropper-HayajneH 2003:173- 
$\boldsymbol{\nabla}$ Ugr.-Arb. * $r \gamma \underline{t}$ 'to suck(le)' is an exclusive isogloss, as recognized in Renfroe 1992:65-66.

13. $\boldsymbol{m} z$ ' 'to tear, be torn' (DUL 607).

- Hapax Legomenon in 1.19 I 36: tmz' $k s t$ dn'il 'she tore the garment of Dn'il'.

- Arb. $m z^{\prime}$ 'II 'to tear' (LA 8 399).

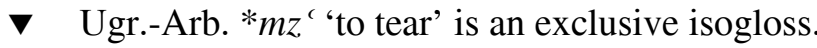

14. rks 'to jump, to leap' (DUL 746).

- Hapax Legomenon in 1.2 IV 15-16: yrtkș șmd bd bl km nšr b 'uṣb th 'the club jumped in $B$ ' 's hands, like an eagle in his fingers'.

- Arb. rqs 'to jump, to dance' (Lane 1136).

$\nabla$ Comparable forms are also attested in MSA, but the possibility of an Arabic loanword is high: Mhr. rəkáwṣ 'to jog up and down' (ML 325), Jib. erkós '(animals) to trample fodder' (JL 213), Soq. rékoṣ 'danser' (LS 407). Semantically related but phonetically somewhat different variant roots elsewhere in Semitic are discussed in CDG 464 and EDG 523-524.

15. šbm 'to muzzle' (DUL 805).

- The principal attestation of Ugr. $\breve{s} b m$ is the much-discussed passage 1.3 III 40, read and translated as $l$ 'ištbm tnn 'ištm $\ulcorner$ dh ' 'je me suis permis de museler le dragon, voulant le détruire' in Bordreuil-Pardee 2004:15. Notwithstanding numerous objections summarized in Barr 1973 and Renfroe 1992:144-145, this interpretation remains the most plausible one (Pardee 1994). Much less certain is $t n^{! ?} n l \breve{s} b m$ tšt in 1.83:8-9 ('you shall put a muzzle on the Dragon' according to DUL 805).

- Arb. šbm 'to put a piece of wood crosswise in the mouth of a kid' (Lane 1499).

$\boldsymbol{\nabla}$ Ugr.-Arb. ${ }^{*} \hat{s} b m$ 'to muzzle' is an exclusive isogloss with no parallel elsewhere in Semitic. ${ }^{16}$

${ }^{15}$ As pointed out to me by Dennis Pardee, a new attestation of this root can now be found in RIH 98.02:5: $n m r$ ḥtrt trḳs '(as) a mighty panther does she pounce' according to PARDEE 2007:35.

${ }^{16}$ Sab. $s_{2} b m$ 'strangling' (BIELla 510) is not recognized in SD. 
16. $\underline{\text { tit }}$ 'mud, clay' (DUL 892).

- Hapax Legomenon in 1.17 II 6-8: th ggk b ym t’tit rḥs npṣk b ym rț 'who plasters his roof in a dirty day, who washes his garment in the day of mud'.

- Arb. ta 'țat- 'black mud' (LA 7 301).

$\nabla$ The exclusive nature of Ugr.-Arb. ta $a$ 't- 'mud' is duly acknowledged in Renfroe 1992:67.

17. $y \boldsymbol{d y}$ 'to rip, to scratch' (DUL 958).

- Hapax Legomenon in 1.5 VI 17-18: $\gamma r$ b 'abn ydy psltm $b$ y' $r$ 'with a stone he scratches incisions on (his) skin, with a razor he cuts cheeks and chin' (Pardee 1997:268).

- Arb. wadyat- 'notch, incision, cut; wounds' (LA 15 451).

$\nabla$ Ugr.-Arb. * $w \underline{d} y$ 'to cut, to scratch' has no cognates elsewhere in Semitic (Renfroe 1992:70-71).

18. $y$ ly 'comrade, companion' (DUL 963).

- Hapax Legomenon in 1.12 II 50-51: šr 'ahh mț'ah w mț'ah šr ylyh 'the prince of his brothers met him, the prince of his comrades met him'.

- Arb. waliyy- 'friend', wly 'to be close' (LA 14 480).

$\nabla$ Ugr.-Arb. ${ }^{*} w \mathrm{~V} l \mathrm{~V} y$ - 'companion' (and the obviously cognate verbal root *wly in Arabic) can be metathetically related to the verbal root *lwy 'to accompany, to join oneself to', attested in Hebrew and Aramaic (HALOT 522). ${ }^{18}$ The formal and semantic proximity between Ugr. $y l y$ and Arb. waliyy- is, nevertheless, so conspicuous that Renfroe (1992:71-74) may be right to consider it an exclusive Ugaritic-Arabic isogloss. ${ }^{19}$

${ }^{17} \mathrm{Mhr} . a w \bar{o} \underline{d i}$ 'to torment, to pester' (ML 422), Jib. $\bar{o} \underline{d i}$ 'to pester' (JL 287) are probably Arabisms.

${ }^{18}$ Phonologically identical verbal lexemes with the meaning 'to turn, twist, to surround' are usually thought to be related as well (cf. CDG 322): Akk. lawû 'to move in a circle' (CAD L 69, AHw. 540), Arb. lwy 'to twist' (Lane 3015), Gez. talawya 'to be twisted, wrapped' (CDG 322), Tgr. läwa 'to walk on roundabout ways' (WTS 45), Tna. läwäyä 'to flex' (TED 120), Mhr. lawu 'to bend' (ML 258), Jib. le 'to turn' (JL 167). Soq. lwy 'saisir' compared in LS 230 is semantically quite remote. Also problematic is Syr. wälēe 'decet' (LSyr. 185) with unexpectedly preserved $w$ - (an early Arabian infiltration?).

${ }^{19}$ But note Sab. wlyt 'protected persons, clients of a clan' (SD 160), Min. twly 'se mêler, s'occuper de' (LM 104). Jib. ōli 'to turn towards' (JL 292) is probably an Arabism. 


\subsubsection{Dubious OR UNRELIABLE}

In this subsection, 21 allegedly exclusive Ugaritic-Arabic lexical features are presented. This selection, quantitatively by far inferior to ca. 100 examples dealt with in Renfroe 1992:75-161, is restricted to well-known isoglosses widely recognized in modern Ugaritological scholarship (notably, in DUL). Not unlike the preceding subsection, my evaluation does not always coincide with Renfroe's: some of my examples (' $m t, b d l, d p r, h m r, k \underline{t} \underline{t}, n g, r g b t, \underline{t}$ 'ar) are missing from his book, whereas a few others ( $n n, h b r, h t \underline{t} t$ ) are listed by Renfroe as reliable instead of spurious and uncertain, which would be more appropriate from my point of view.

1. 'dmt 'desolation' (DUL 150) - Arb. 'dm 'to lack, to miss', 'udm- 'lack, loss, poverty, destitution' (Lane 1975-1976).

- Attested in 1.161:17 in the exclamation ' $d m t w^{\prime}$ ' $d m t$ ' $d m t$, variously understood as "desolation, desolation, yes of desolations" (del Olmo Lete 2004:195), "a metathesis of $d m^{\prime} t$ 'tears', resonanting the prothetic form $u d m$ 't in the previous line" (Levine-de Tarragon-Robertson 1997:358) and "how long?" = Akk. adi mati, Hbr. 'ad mātay (cf. most recently Gzella 2007:534). As Renfroe (1992:88) correctly observes, "the comparison with Arabic 'dm 'loss, destitution, lack' is credible, but improvable."

2. ' $m t$ 'to hit' (DUL 166) - Arb. ' $m t$ 'to beat with a stick' (TA 5 11).

- Hapax Legomenon in the difficult passage 1.16 VI 8-9 (htm t'mt ptr km zbln ' $\mathrm{r}$ ' 'išh). Del Olmo Lete's interpretation 'con una vara golpeó abriendo brecha, y exterminando/desapareció la enfermedad de su cabeza' (1981:320) is attractive, but hardly compelling (left untranslated in Pardee 1997:342).

3. 'nn 'manservant, assistant' (DUL 170) - Arb. 'wn IV 'to help' (Lane 2203).

- The meaning 'servant' is suitable in some of the relevant contexts (e. g. 1.4 IV 59-62: $p$ 'bd 'an ' $n n$ 'atrt $p$ 'bd 'ank 'ahd 'ult $\mathrm{hm}$ 'amt 'atrt tlbn lbnt 'am I a servant, an attendant on 'atrt? am I a servant who holds a trowel? is 'atrt a maidservant who makes bricks?'), but derivation from * ' $w n$ as envisaged in Renfroe 1992:22-24 is faced with serious morphological difficulties. At any rate (as Renfroe correctly recognizes), this isolgoss is not exclusive since * $w n$ 'to help' is well attested also in Sabaic: $h$ - $n$ 'to aid, to help, to protect' (SD 23). 
4. $\boldsymbol{b} \boldsymbol{d} \boldsymbol{l}, \boldsymbol{b i - d a - l u - m a}$ 'substitute, reserve personnel' (DUL 217, Huehnergard 1987:112) - Arb. $b d l$ 'to change, to exchange, to replace' (Lane 167).

- The meaning and the origin of the Ugaritic term are extensively discussed in Schloen 2001:226-230. The Arabic etymology is potentially suitable to explain both the widespread translation 'substitute' and the now less popular interpretation 'merchant'. ${ }^{20}$ If accepted, Ugr.-Arb. *bdl 'to exchange' would represent an exclusive isogloss. ${ }^{21}$ However, morphological peculiarities made apparent by the syllabic spellings of Ugr. $b d l$ - namely, the pattern $* \mathrm{C}_{1} i \mathrm{C}_{2} \bar{a} \mathrm{C}_{3}-$, highly atypical for a professional designation (cf. Tropper 2000:181), and nunation instead of mimation in the alternative plural form bi-da-lu-na (ibid. 294) - cast serious doubts on the validity of this comparison and make one think of a non-Semitic (possibly Hurrian) origin of Ugr. bdl/bidalu (Schloen 2001:227, notwithstanding Huehnergard's objections in 2008:391-392).

5. bldn 'land' (DUL 222) - Arb. balad- 'country, land' (Lane 247).

- Attested in 1.91:6 and 1.162:1 in the combination 'il bldn. The translation 'gods of (our) country' is widely accepted (Pardee 2000:503, del Olmo Lete 2004:260), but remains conjectural in spite of the hypothetic parallelism with DINGIR.MEŠ ša KUR $u$-ga-ri-it in PRU 3 18:6-7. As for bld in 1.22 I 18, "that bld $\gamma l l$ might have meant 'the district of $\gamma l l$ ' is possible, but undemonstrable" (Renfroe 1992:90) ${ }^{22}$.

6. $\boldsymbol{d p r}$ 'to exhude a strong smell' (DUL 277) — Arb. dafr- 'to stink', dafir'stinking' (Lane 890).

- Hapax Legomenon in 1.22 I 16 ( $\left.d p r \underline{t} l \underline{h n} b k^{\prime} l\right)$. The passage is very obscure and DUL's translation 'the table exuded a strong smell' is merely conjectural. Arb. $d f r$ has no reliable cognates elsewhere in Semitic. ${ }^{23}$

${ }^{20}$ Contrast Huehnergard 1987:112 and HueHnERGard 2008:390

${ }^{21}$ Comparable terms in Ethiopian Semitic and MSA — Tna. bäddälä 'to exchange, barter' (TED 1196), Mhr. abōdal 'to change' (ML 43), Jib. ōdal 'to change' (JL 22), Soq. $b d l$ 'être changé' (LS 82) - are likely borrowed from Arabic. The traditional equation between Arb. $b d l$ 'to (ex)change' and Hbr. $b d l$ 'to withdraw, to separate' (HALOT 110) is hard to justify semantically. In view of the high degree of graphic ambiguity, the widespread identification between BA-DA-LUM in Ebla with either Arb. $b d l$ or Ugr. $b d l(m)$ (e. g. FronZAroli 1984:156-157) is at best conjectural.

${ }^{22}$ Interpreted as $b l d \gamma l l$ 'wine into the goblet? of intoxication ?' in DUL 494.

${ }^{23}$ Tgr. däfrät 'breath, smell, scent' (WTS 544) is clearly an Arabism. Since Arb. dfr also means 'to be base, abject, vile' (Lane 890), Jib. défar 'bad' (JL 35) can be borrowed from Arabic as well. Note, moreover, that according to a personal communication by Dennis Pardee a recent collation has shown the first sign of the relevant Ugaritic word is 'upr rather than $d p r$. 
7. $\boldsymbol{g} \boldsymbol{b l}$ 'summit, mount' (DUL 293) — Arb. ̌̌abal- 'mountain' (Lane 376).

- Hapax legomenon in 1.3 VI 7-8 ([ ' $b r g b l$ ' $\left.b r k^{\prime} l\right)$. The translation 'mountain' is possible ('cross the mountain, cross the height' in Pardee 1997:255), but hardly compelling (v. Renfroe 1992:103-104 and 139-140 for the alternative translation 'Byblos', tentatively accepted in Parker 1997:118, 169). ${ }^{24}$

8. $\gamma l l$ 'thirsty one' (DUL 319) — Arb. $\gamma l l$ 'to be thirsty' (Lane 2277).

- Hapax Legomenon in 1.12 II 34 (context partly broken), supposed to be paralleled by 'aklm 'the devourers', present throughout this text. Identification with Arb. $\gamma l l$ is possible, but by no means compelling (cf. Renfroe 1992:107).

9. $\boldsymbol{\gamma}$ t 'to gulp down' (DUL 323) — Arb. ynt 'to drink' (LA 2 196).

- Hapax Legomenon in 1.108:11 in a partly broken context. As pointed out in Renfroe 1992:108, "the proximity of this word to $w$ yšt 'il 'God drinks' in line 10 of this text has prompted some to compare the word with Arb. yanata 'to drink a draught, then take a breath'. The structure of the text suggests much more that the word be understood as a name or epithet of a deity."

10. $\boldsymbol{h b r}$ 'to bow' (DUL 333) — Arb. habr-, habir- 'depressed area surrounded by higher ground' (LA 5 290).

- Passim in the prostration formula (e. g. 1.3 III 9-10: $l$ p'n ' $n t h b r w k l$ 'to ' $n t$ 's feet they bowed down and fell') as well as in 1.23:49 (yhbr špthm yšk 'he bowed down and kissed their lips'). The semantic relationship between the Ugaritic verbal root and the topographic terms in Arabic is far from certain (cf. Renfroe 1992:42-45).

11. $\boldsymbol{h} \boldsymbol{b} \boldsymbol{t}$ 'to knock down, to hit; to remove, to wipe out' (DUL 334) - Arb. $h b t$ 'to go down, to be lowered, degraded', 'to beat, to strike', 'to remove' (Lane 2876).

Reliably attested in letters only (Dijkstra 1975). The best preserved example is 2.61:3-7 (bn hrnk $m \gamma y$ hbt hw hrd $w$ šl hw krrt), where both meanings

${ }^{24}$ The same reasoning applies to the parallel $k l$ (RENFroE 1992:139-140), which can be identified with the Canaanite geographic term (Hbr. $k a \bar{i} q \bar{a}$, HALOT 1116) instead of the Arabic appellative $q \bar{a}$ 'ilat- 'a tall mountain' (LA 11 666). 
suggested by the Arabic etymology ('to strike' and 'to abase') can fit. ${ }^{25}$ More difficult is $\check{s} p h$ 'al thbt in 2.47:16, translated as 'tu ne permettras que le clan soit abaissé' in Bordreuil-Pardee 2001:382, where this passage is extensively discussed in connection with the double attestation of $h b t$ (in damaged contexts) in the letter RSOu 14 51. Very obscure is 2.4:18-20 (ht yšm ' 'uhy l gy w yhbt bn?! s w yth 'ilm bdhm). ${ }^{26}$ For the problematic thbth in 1.163:3 see, finally, Pardee 2000:866. Summing up, "le sens précis de HBṬ nous échappe encore" (Pardee 2000:866), which makes this verb unsuitable for a diachronically meaningful lexical isogloss (Renfroe 1992:114-115). ${ }^{27}$

12. hag 'birth-chair' (DUL 354) — Arb. hiď̌- 'a certain thing upon which the women of the Arabs of the desert ride' (Lane 530).

- Hapax Legomenon in 1.12 I 17-19, where it is listed among objects necessary for the birth process $(k h k s$ 'ank $h d g k h t l k$ 'take your chair, your "saddle", your swaddling cloth ${ }^{28}$ ). This identification is widely accepted, but, as Renfroe rightly points out (1992:117-118), the realia behind it are obscure and it is preferable to refrain from treating it as a reliable exclusive isogloss. There is no suitable verbal root elsewhere in Semitic from which either the Arabic or the Ugaritic terms could be reasonably derived.

13. hmr 'red, reddish' (DUL 364) - Arb. ḥmr IX 'to be red' (Lane 640).

- $\quad$ Attested in hippiatric texts (e. g., 1.85:17) as an attribute of 'aryn/'iryn, which denotes a materia medica. The translation 'red' (Cohen-Sivan 1983:3132 ) is arbitrary. The same is true of the alternative interpretation 'donkey'.

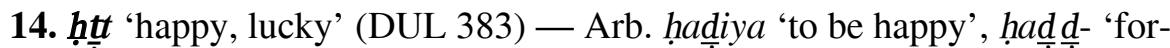
tune' (Lane 595-596).

- Hapax Legomenon in 1.3 V 30-31: tḥmk 'il ḥkm ḥkmk 'm 'Im ḥyt ḥțt thmk 'your decisions, 'il, are wise, your wisdom is forever, your decision(s) provide a life of good fortune' (Pardee 1997:254). Even if this widely accepted in-

${ }^{25}$ Cf. TROPPER's translation 'PN kam, schlug die huradu-Truppe nieder, und plünderte die Stadt' (2000:702).

${ }^{26}$ Cf. Renfroe 1992:114 ("the usual interpretation of $h b t$ is out of place here") and PARDEE 2000:866 ("la polarité négative [...] est difficile").

${ }^{27}$ In DUL 334, Sab. $h b t$ is adduced, which would make this isogloss not exclusive. However, as pointed out in RENFROE 1992:115 and GzELLA 2007:542, the very existence of the Sabaic verb is doubtful.

${ }^{28}$ STOL 2000:121. 
terpretation is correct, the Ugaritic-Arabic isogloss is (contra Renfroe 1992:5256) by no means exclusive, cf. Sab. hțy 'favor', yḥtțyw 'to be successful' (SD 75), Min. hțy 'obtenir des auspices favorables', hțy 'faveur' (ML 51), Mhr. hạd 'luck, share' (ML 167), probably also Gez. haș̂e 'title of the emperors of Ethiopia' (CDG 226, with discussion). ${ }^{29}$

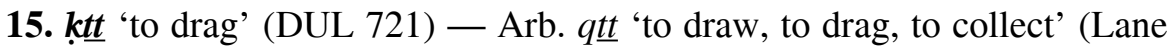
2487).

- Hapax Legomenon in 1.2 IV 27: yḳt $b^{\prime} l w$ yšt ym. The commonly accepted interpretation of this passage — ' $B$ ' l grabs $Y m$ and sets about dismembering him' (Pardee 1997:249, cf. Parker 1997:104, del Olmo Lete 1981:177) - is by no means certain and, at any rate, the translation 'he grabs' for $y \underline{k} \underline{t}$ is derived from etymology rather than from context. The meaning of the reduplicated stem $k \underline{t k} \underline{t}$ in 1.114:5-6 ( km $k[l] b$ y $k \underline{t k} \underline{t} \underline{t} t \underline{t} t \underline{t} l \underline{h n t})$ is even more obscure, $\mathrm{v}$. extensively Pardee 1988:42-43.

16. $\boldsymbol{m}$ ' 'as one, together' (DUL 519) — Arb. $m a^{\text {' }} a^{n}$ 'together' (LA 8 405).

- Hapax Legomenon in 1.14 II 32-35: 'dn ngb w yṣ 'i șb'u șb'i ngb w yṣ 'i ' $d n m^{\prime} s b^{\prime} u k$ 'ul $m^{\prime} a d$. Although there is no unanimously accepted understanding of the syntax of this passage, comparison with Arb. $m a^{\prime} a^{n}$ 'together' is certainly not the only way of interpreting $m$ ' in this context ('a throng will indeed ${ }^{30}$ go forth' in Pardee 1997:334 and cf. Tropper 2000:813, Renfroe 1992:128).

17. $n g$ 'to go away, depart' (DUL 624) — Arb. nگ̌w 'to go out, to escape' (Lane 3028)

- Hapax Legomenon in 1.14 III 27-29, meaning clear from context (ng mlk $l$ bty 'depart, king, from my residence', paralleled by rḥk krt $l$ ḥtry 'keep far off, Krt, from my abode').

- The only cognate for the Ugaritic form adduced in DUL 624 is Arb. $n \check{z} w$, but PCS * $n g w$ is also attested in ESA: Sab. $n g w$ 'to give out', $m n g w$ 'event, incident, outcome' (SD 94), Min. ngw 'promulger, notifier, proclamer' (LM 66), Qat. mngw 'result, outcome' (LIQ 102). ${ }^{31}$

${ }^{29}$ As is well known, the whole scope of meanings connected with favor, luck etc. eventually goes back to PS *hWttt- 'arrow' (RENFROE 1992:54-55) with a meaning shift also present in Arb. sahm- 'arrow; lot, portion' (LANE 1454).

${ }^{30}$ Italics added.

${ }^{31}$ Tgr. näga 'to be clean' (WTS 342), Mhr. nīgi 'to be free' (ML 288), Jib. nígi 'to survive' (JL 184), Soq. ngy 'délivrer' (LS 256) are Arabisms. 
18. $\boldsymbol{n k t}$ 'to immolate' (DUL 631), $m k t$ 'immolation, offering' (ibid. 545) Arb. $n k t$ 'to strike with a stick; to throw upon the ground; to thrust, to pierce' (Lane 2846).

- The most reliable attestation is 1.40:32-33: $d b h n n d b h h w \underline{t}^{\prime} n \underline{t}^{\prime} y \mathrm{hw} n k t$ $n k t$ 'le sacrifice, il est sacrifié, l' offrande, elle est offerte, l' abattage est fait' (Pardee 2000:97-98). Less transparent are 1.86:4 ( $w$ prt tkt 'you? immolate a cow', context broken) and 1.48:16 ('aht l mkt 'one for the offering of...', context bro$\mathrm{ken}^{32}$ ). Notwithstanding Renfroe's objections (1992:134-135), one has to agree with Aartun (1968:278) and Pardee (2000:127-128) that comparison with Arb. $n k t$ is the best (probably, the only) way of explaining $n k t n k t$ in 1.40:33. The Ugaritic-Arabic isogloss is, nevertheless, not exclusive, since clearly related terms are well attested in Ethiopian Semitic: Tna. näkätä 'to drive in (a dart); to hit a branch or hedge with a stick', mankat 'beating' (TED 1342-1343), Amh. näkkätä 'to break, to smash' (AED 1046).

19. $\mathbf{n z l}$ ' 'offering' (DUL 655) - Arb. nuz(u)l- 'food prepared for the guest' (Lane 3031).

- Hapax Legomenon in 1.14 III 55-59: lkh 'imr dbḥ b ydh ll'a kl'atnm klt lhmh d nzl lkh msrr 'ṣr $d b[h]$ 'he took a sacrificial lamb into his hands, a kid with both (of his hands), a measure of his bread of offering he took, the entrails of a sacrificial bird'. As rightly observed in Renfroe 1992:136-137, the meaning of the Arabic noun can only be secondary with respect to the basic meaning of the root $n z l$ in Arabic, viz. 'to descend' ( $>$ 'to stop, to sojourn, to abode, to lodge in a place', Lane 3001), note in particular nazil- 'guest' (ibid.). Arb. nuzul- is therefore unsuitable for direct comparison with phonologically similar terms in other Semitic languages. Since no alternative cognate term is at hand, the expression lhmh $d n z l$ still awaits a meaningful contextual and etymological interpretation.

20. $\boldsymbol{r} \boldsymbol{g} \boldsymbol{b t}$ 'respect, fear' (DUL 732) - Arb. $r \breve{z} b$ 'to be frightened, afraid' (Lane 1033).

- Attested in 1.112:4 (list of sacrifices) in the expression s' $r g b t$, interpreted as 'platter of respect' in DUL. No such meaning can be deduced from the context (cf. Pardee 2000:637-638 for a different, albeit no less arbitrary, interpretation 'mottes de terre'). Even less certain is 1.133:19 ( $r g b t ~ z b l$ 'the fear of the Prince' in DUL vs. 'la motte du Prince' in Pardee 1988:162). No coherent interpretation has been proposed so far for $\check{s}^{\prime}[h] \mathrm{rgbt} y^{\prime} u[h] b$ in 1.92:31-32.

${ }^{32}$ Cf. PARdeE 2000:332. 
21. $\underline{t}^{\prime} a \boldsymbol{r}$ 'avenger (of blood)', $\underline{t} \boldsymbol{r} r$ 'to avenge blood' (DUL 891-892) - Arb. $\underline{t}$ 'r 'to revenge one's blood' (Lane 327).

- The Arabic root has been widely used to interpret the difficult passage $\underline{t} a^{\prime} r$ 'um tkn $l h$ (1.14 I 15), but no satisfactory result has been obtained so far. ${ }^{33}$ The verbal form in 1.2 III 21 (yt'ir $\underline{t} r$ ' $i l$ ' $a b h$ ) is also usually interpreted on the basis of the Arabic cognate, but here too the details remain obscure. ${ }^{34}$ The translation 'your seven "avengers" for $\breve{s} b^{\prime}$ t'irk in 1.18 I 25 (DUL 892) is of necessity conjectural because of the heavily damaged context. Finally, tt $a r$ in 1.3 II 37 is probably a mistake for $t \underline{t}^{\prime} r$ (with DUL 891). At any rate, the Ugr.-Arb. isogloss is not exclusive, since $t^{\prime} r$ 'blood revenge' is also attested in Sabaic (SD 149).

\subsection{Ugaritic-Aramaic}

Since potentially exclusive lexical isoglosses between Ugaritic and Aramaic are extremely few, reliable examples will be listed below side by side with more problematic ones.

1. $\boldsymbol{d h}$ l 'to fear' (DUL 269).

- Supposed to be attested in 2.16:10-12: w 'um ... 'al tdhln 'and let my mother ... be not afraid'. The reading with $-d$ - is suspect ${ }^{35}$ whereas $t d h \underline{\text { ș seems }}$ to be written in a similar context in 2.30:21 (Bordreuil-Pardee 2004:85).

- Common Aramaic * $\underline{d} \underline{h l}$ id. (HALOT 1850, LSyr. 148).

$\nabla$ Possible cognates of Ugr.-Arm. * $\underline{d} \underline{h l}$ are discussed in Kogan 2005:526.

2. $\operatorname{grdš~'to~be~undermined,~ruined'~(DUL~307).~}$

- Hapax Legomenon in 1.14 I 10-11: krt ḥtkn rš krt grdš mknt 'Krt — his family was crushed, $K r t$ — his home was destroyed' (Pardee 1997:337).

${ }^{33}$ Cf. TROPPER 1995a where KTU's reading is abandoned in favor of tht 'un. The traditional reading is re-affirmed (even without restoration marks) in BORDREUIL-PARDEE 2004:20. Comparison with Lev 18:6 in PARDEE 1997:333 is, however, hardly attractive, as it implies that Ugr. t'ar ('kin' in Pardee's interpretation) is related to Hbr. ša'e $r$ 'flesh', whose regular formal and semantic cognate is Ugr. šir 'flesh' (DUL 797, also PARDEE 2000:1165), see further SED I No. 238 and TROPPER 1995a:530. The same is true of PARDEE's analysis of šb' t'irk in 1.18 I 25 (1997:394). Note that according to Pardee (personal communication) the Hebrew word for 'kin' in passages like Lev 18:6

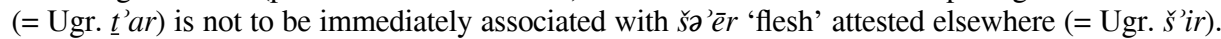
In my opinion, this proposal is hard to reconcile with the fact that also Hbr. $b \bar{a} \hat{s} \bar{a} r$ 'meat, flesh' is widely attested with the meaning 'kin' (BDB 142), note especially the combination ša 'êr bəŝârō.

${ }^{34}$ Contrast 'the Bull, his father 'Ilu may take blood vengeance' (PARDEE 1997:248), 'may Bull El his Father take vengeance?' (Parker 1997:97) and 'bull DN stood surety' (DUL 890).

${ }^{35}$ Cf. $t w h l n$ in Bordreull-PARDEE 2004:84. 
- Syr. gardeš 'erosit' (LSyr. 132). The semantic overlap between Ugaritic and Syriac is far from complete. Besides, attestations of the Syriac verb are rare and late, and the root does not seem to be present anywhere else in Aramaic.

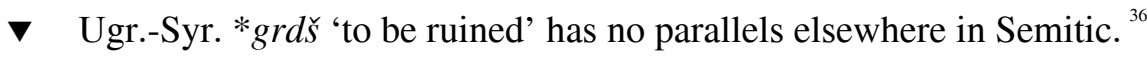

3. $\boldsymbol{n h t}$ ' 'to take down' (DUL 628).

- Attested in 1.23:37 ('il buth nḥt 'il ymnn $m t$ ydh ' 'il lowers his staff, 'il grasps his rod in his right hand ${ }^{, 37}$ ) and elsewhere in this text. ${ }^{38}$

- Common Aramaic *nht 'to go down, to descend' (DNWSI 726, HALOT 1929, LSyr. 424).

$\nabla$ Possible cognates of Ugr.-Arm. *nhtt 'to go down' are discussed in Kogan 2005:523-524.

4. šdy 'to pour' (DUL 811).

- Hapax Legomenon in 1.6 IV 18: $\check{s} d y n$ ' $n b k b^{\prime} t$ 'pour sparkling wine into a goblet' (translation from DUL 692).

- Common Aramaic * $* \check{s} d y$ 'to throw, to pour' (LSyr. 757, DJBA 1109, DJPA 538).

$\nabla$ Ugr.-Arm. * ${ }^{\prime} d y$ 'to pour' has no direct cognate elsewhere in Semitic. ${ }^{39}$

5. škh 'to meet', N 'to be met, welcomed' (DUL 814).

- Thought to be attested in 2.38:13-15: by gšm 'adr nškh 'they found themselves in a heavy rain'. Potentially relevant forms in 2.73:14 (tšk $h$ ) and 2.73:19 (nšk $[h])$ are hard to evaluate because of the broken context.

- Common Aramaic *škḥ 'to meet, find' (DNWSI 1132, LSyr. 775).

${ }^{36}$ There is, conversely, a remarkable semantic proximity between Ugr. grd $\check{s}$ and Mhr. angardō̂s, Jib. angerdés 'to fall down' (ML 124, JL 78). MSA $\hat{s}$ is compatible with Ugr. š but not with Syr. š. Cf. also Amh. gäräddäsä 'to break a stick, to fell a large tree' (AED 1943).

${ }^{37}$ Translation from PARDEE 1997:280-281 (with commentary). Note that in BoRDREUIL-PARDEE 2004:29 the translation 'Ilu prépare sa verge' has been preferred (personal communication Dennis Pardee).

${ }^{38}$ As TROPPER reasonably suggests (1995b:60), ynḥt in 1.2 IV 11 ( $k \underline{t r}$ șmdm ynḥt) may belong to a different Ugaritic and Common Semitic root *nht 'to cut, to trim'.

${ }^{39}$ Arb. $s d w$ 'to stretch one's legs' tentatively compared in LSyr. 757 is semantically quite remote. More attractive is Brockelmann's alternative comparison, namely sud ${ }^{n}$ 'left, let alone, neglected' (LANE 1336). Cf. also $s d w$ 'to play with walnuts throwing them into a hole' (LANE 1336). 
$\boldsymbol{\nabla}$ The etymological background of Ugr.-Arm. *škh 'to find' is discussed in Kogan 2005:561.

\subsection{Ugaritic-Akkadian}

1. 'ugr 'field, soil' (DUL 27).

- Hapax Legomenon in 1.12 I 23-25 (kry 'amt 'pr 'ț yd 'ugrm 'dig your elbow into the dust, the bone of your hand, into the soil'). Although the precise meaning of this difficult text is uncertain (cf. Stol 2000:121), parallelism with ' $p r$ 'dust' makes the translation 'into the soil' for 'ugr-m highly probable.

- Akk. ugāru 'Feldflur, Ackerland' (AHw. 1402).

$\boldsymbol{\nabla}$ The Akkadian lexeme is thought to be borrowed from Sum. a g à r (PSD A 1 78, Lieberman 1977:511-512).

\section{2. 'mr 'to look at' (DUL 71).}

- The most reliable attestation is 1.3 I 22-24, where the meaning 'to look at' seems to be assured by the parallelism with ' $n$ 'to see' (ytmr bl bnth y' $n$ pdry bt 'ar 'apn tly bt rb 'B' l looks at his daughters, he sees Pdry, daughter of 'ar, also Tly, daughter of $R b^{\prime}$ '). Considerably less certain is 'išt 'ištm y'itmr 'they look like? one fire, two fires' (1.2 I 32), whereas the meaning of y'amr in 1.172:22 cannot be ascertained because of the broken context. In spite of its somewhat sparse attestation, the existence of Ugr. ' $m r$ 'to look at' is widely accepted in Ugaritological literature (v., in particular, Tropper 2000:519-520 for the grammatical problems involved).

\section{- Akk. amāru 'to see' (AHw. 40, CAD A 2 5).}

$\boldsymbol{\nabla}$ The extraordinary complex semantic history of the root *'mr cannot be reassessed here, but if one follows Moscati (1946:125) and Albright (1954:229) in regarding the meaning 'to see' as the original one, ${ }^{40}$ Ugaritic must be the only Semitic language where this archaic meaning is attested virtually side by side ${ }^{41}$ with the innovative 'to say, to command', normal for the rest of CS. ${ }^{42}$

\footnotetext{
${ }^{40}$ For possible semantic parallels in Indo-European v. BUCK 1949:1257, RUNDGREN 1963:181 (contrast SANMARTín 1973:267).

${ }^{41}$ In 1.2 I 31: 'amr 'order, demand' (DUL 72).

42 The specificity of the Ugaritic picture is duly recognized in HALDAR 1964:275 and SANMARTín 1973:267-270. Remnants of the original meaning 'to see' have been surmised for ' $m r$ in other CS languages as well (for Hbr. ' $m r$ 'to see' v. DAHOOD 1963:295-296, for Arb. 'amarat-, tu'mur'sign, mark', LANE 97-98, v. Moscati 1946:124, RundGREN 1963:182), but they are much less certain. It would be tempting to regard the meaning shift 'to see' $>$ 'to say' as a shared semantic innovation of CS, but cf. common MSA * 'mr 'to say' (Mhr. 'āmōr, Jib. 'õr, Soq. 'émor, ML 25, JL 13, LS 315), which is hard to separate from this root in spite of the irregular *'.
} 
3. 'išd 'leg' (DUL 116).

- Reliably attested in 1.3 III 19-20 ('my p'nk tlsmn 'my twth 'išdk 'let your feet run to me, let your legs hasten to me'), where the meaning 'leg' is clear from the parallelism with $p^{\prime} n$, the basic term for foot in Ugaritic. See also 1.101:5-6 (r'išh tply tly bn 'nh [...] 'uz'rt tmll 'išdh krn [...] bt 'Th 'Tly lui épouille la tête, $[\ldots .$.$] "entre les yeux", 'uz'rt lui frotte les pieds, B t$ ' $t h$, les cornes', Pardee 1988:125).

- Akk. išdu 'base, foundation, bottom, lower extremities' (AHw. 393, CAD I 235).

$\boldsymbol{\nabla}$ Akk.-Ugr. * 'išd- 'leg' may be ultimately related to a variety of anatomic and non-anatomic terms elsewhere in Semitic (v. SED I No. 255), but only Akk. išdu and Ugr. 'išd match exactly from the phonological point of view. ${ }^{43}$

4. 'ušr 'penis' (DUL 118).

- Hapax Legomenon in a divinatory compendium (1.103+:47). The present interpretation, although fully dependent on the Akkadian etymology, is widely accepted (e. g. Pardee 1997:289).

- Akk. išaru, ušaru 'penis' (CAD I 226, AHw. 392).

$\nabla$ Akk.-Ugr. *'V̌̌Vr- 'penis' has no parallel elsewhere in Semitic. If the Akkadian and Ugaritic terms are related as cognates, the traditional derivation of Akk. išaru from ěseru 'to be straight' $(<* y \check{s} r)^{44}$ becomes impossible.

5. 'mk 'tough, strong' (DUL 165).

- Hapax Legomenon in 1.17 VI 45: n'mn 'mk nšm 'good and strong among men'. This almost universally accepted interpretation entirely depends on the Akkadian etymology. ${ }^{45}$ It is uncertain whether the syllabic am-ka reflects the same basic meaning ('stronghold", Huehnergard 1987:160) or rather belongs to ' $m k$ 'to be deep' ('plain', van Soldt 1991:306).

${ }^{43}$ Needless to say, the semantic difference between Akk. išdu and Ugr. 'išd cannot be disregarded. Although there are good reasons to suspect that Akk. $i \check{s} d-\bar{a} n$ was originally an anatomic term, in most of its extant attestations this meaning is by no means apparent. Curiously enough, purely anatomic meaning 'foot, leg' is only attested in historical and literary texts of the $1^{\text {st }}$ millennium (listed under 'lower extremities, stance' in CAD I 240, meaning f).

${ }^{44}$ AHw. 392: išaru B = išaru A, i. e. 'penis' = 'straight'. Less explicit also CAD I 226. For the same conclusion reached on the basis of the Ebla gloss $\breve{s} e-n e-b u_{16}$ wa ì-sa-lum (= Sum. KUN) in VE 1372' v. KREBERNIK 2006:85.

${ }^{45}$ The same is true of GzelLA's feasible alternative 'clever' = Akk. emku (2007:536). 
- Akk. emūku 'strength' (AHw. 216, CAD E 157).

$\boldsymbol{\nabla}$ The origin of Akk.-Ugr. * ' $m k$ 'to be strong' is uncertain. Hypothetic WS cognates with the meaning 'strength' (notably, Hbr. 'émäk) are quite doubtful (with HALOT 849 and contra Greenfield 1967:89). ${ }^{46}$ There is no transparent semantic link between Akk.-Ugr. * ' $m k$ 'to be strong' and * ' $m k$ 'to be deep' widely attested throughout WS. ${ }^{47}$ According to CAD E 161, Akk. emūku 'strength' is, in its origin, an anatomic term ('arm'), but there is no etymological support for this conjecture. ${ }^{48}$

6. 'rb 'to enter' (DUL 179).

- Passim in the Ugaritic corpus.

- Akk. erēebu 'to enter' (AHw. 234, CAD E 259).

$\nabla$ Ugaritic is the only WS language where * ' $r b$ fully preserves its (presumably, original) status of the main exponent of the meaning 'to enter'. ${ }^{49} \mathrm{El}-$ sewhere in WS, only derived meanings such as 'to set (sun)' or 'to stand surety' are attested (for which v. HALOT 876, CDG 69). ${ }^{50}$

7. $\boldsymbol{h w t}$ 'word, statement' (DUL 349).

- Passim in the Ugaritic corpus. 29).

- Akk. awatu 'word, utterance; matter, affair, thing' (AHw. 89, CAD A

$\boldsymbol{\nabla}$ The origin of Akk.-Ugr. *hawat- 'word; matter' (Haldar 1964:275), ultimately related to the verbal root *hwy 'to speak' underlying Akk. atw $\hat{u}$ 'to discuss, to talk over' (AHw. 89, CAD A 29, Goetze 1947:244-245, Kouwenberg 2008), is uncertain (cf. DRS 386).

${ }^{46}$ Somewhat more promising are Tgr. 'ammäkä 'to rob, to defraud' (WTS 456), Amh. ammäkä 'to oppress, to rule by force' (AED 1126).

${ }^{47}$ Well attested in Ugaritic (in the derived noun with the meaning 'valley', DUL 165), but missing from Akkadian, unless one accepts its traditional identification with emēku 'to be wise' (AHw. 213, CDG 63) - semantically far from evident (application of modern concepts like 'deep knowledge' seems anachronistic). Curiously enough, Akkadian has no special verb for 'to be deep', this meaning being expressed by šapālu 'to be low' (CAD Š ${ }_{1} 422$ ).

${ }^{48}$ Of some interest may be Tna. 'ammokä 'to hit hard (with an elbow)', mə 'amak ${ }^{w}$ 'thrashing, striking with a bent elbow' (TED 1835).

${ }^{49}$ Cf. von Soden's remark "ug. ' $r b$ wie akk." in AHw. 234.

${ }^{50}$ Both of these derived meanings are attested in Ugaritic as well as in Akkadian: ' $r b$ 'sunset', 'rbn 'guarantor, surety' (DUL 183), erebu 'setting of the sun', erubātu 'pledge' (CAD E 258, 327).

${ }^{51}$ It is still uncertain whether Hbr. hawwā and hōwa are indeed to be translated as "words" 
8. hapr 'ration, supply' (DUL 366).

- Passim in economic documents.

- Akk. ipru 'barley ration, food allowance' (AHw. 385, CAD E 166), epēru 'to provide with food rations' (AHw. 223, CAD E 190).

$\boldsymbol{\nabla}$ The origin of Akk.-Ugr. *hpr 'to provide with food' is uncertain.

9. brn 'gang, caravan' (DUL 405).

- The most reliable attestation is $1.4 \mathrm{~V}$ 29-31: ș̣ hrn b bhtk ' $\underline{d} b t$ t $b$ krb $h k l k$ 'call a gang to your house, a squad to your palace'. The meaning 'messenger' (lit. "son of the road") is usually postulated for bn brnk in 2.61:3, but

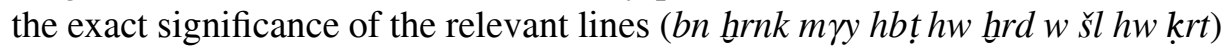
remains uncertain (cf. Singer 1999:726).

- Akk. harrānu 'road; caravan; business venture; service unit' (AHw. 326, CAD H 106).

$\boldsymbol{\nabla}$ The etymology of Akk.-Ugr. *harrān- 'road, caravan, gang' is unknown. Huehnergard's comparison with Arb. hrr II 'to set free; to point, to adjust' $(2003: 105,116)$ is hardly appealing from the semantic point of view, the more so since the meaning 'to set free' is obviously derived from hrr I 'to be free', hurr- 'freeborn' (Lane 538), with transparent cognates elsewhere in CS (HALOT 348). Semantically more suitable could be Gez. harā 'army, troops' (CDG 240), usually derived from the same root. ${ }^{52}$

10. $b t$ ' 'sceptre, rod, wand, stake' (DUL 414).

- Widely attested, the most reliable examples include 1.6 VI 28-29 ( $l$ yhpk $k s^{\prime} a$ mlkk $l y \underline{t} b r h t$ t $m t \underline{t} t k$ 'he will surely overturn the throne of your kingship, will break the sceptre of your rulership'), 1.23:8-9 (bdh ht tkl bdh ht 'ulmn 'the rod of bereavement is in his hand, the rod of widowhood is in his hand), 1.23:37

(DCH 2 502-503, cf. HALOT 242) instead of the traditional "desire" and "destruction" in passages like Ps 38:13 (dōrəšse rā 'ātī dibbarū hawwōt), Ps 52:4 (hawwōt taḥšōb ləšōnäkā), Mc 7:3 (haggādōl dōbēer hawwōt napšō), Jb 6:30 ('im hikkkīlōo(') yābinn hawwōt), Ez 7:26 (hōwā 'al hōwā

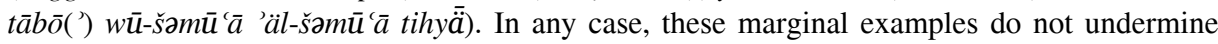
the fundamental agreement between Akkadian and Ugaritic in what concerns the basic status of awatu/hwt. Arb. hwt II 'to call' compared in DUL 349 is hardly related, being rather a by-form of hyt II 'to call someone saying hayta hayta' (LANE 2910). More promising could be Arb. haw''mind, purpose, desire' (LANE 2904).

${ }^{52}$ Huehnergard does not mention Ugr. hrn, but on p. 111 of his study he admits that the apparently unmotivated fluctuation between $h$ and $h$ is attested not only between WS and Akkadian, but also within West Semitic (with several instructive examples). 
('il hth nht 'il ymnn mt ydh ' il lowers his rod, he takes the staff into his right hand?'), 1.114:7-8 (w d l yd'nn ylmn hṭm tḥt tllhn 'and one who does not know him strikes him with a stick under the table'), 1.169:5 (ht $n k h$ ' $u k r b$ ht 'the rod is ready?, or the rod is near').

\section{3).}

Akk. hatț 'scepter, staff, stick, branch, twig' (AHw. 337, CAD H

Akk.-Ugr. *hatt- 'rod' has no reliable cognates. ${ }^{53}$

11. $\mathbf{k m s}$ 'to buckle, to bend' (DUL 446).

- Hapax Legomenon in 1.12 II 53-54: $n p l$ b' l km tr w tkms hd km 'ibr 'B' l fell like a bull, $H d$ kneeled down like a steer'.

- Akk. kamāsu 'to squat, to kneel' (AHw. 431, CAD K 117).

$\boldsymbol{\nabla}$ Akk.-Ugr. *kms is vaguely reminiscent of Akkadian and WS anatomic terms denoting articulation, joint (Akk. ḳimșu, Hbr. ḳamāṣīm, SED I No. 172), but no phonologically exact cognate has been detected so far.

12. $\boldsymbol{k} \check{\boldsymbol{s}} \boldsymbol{d}$ 'to search for, to reach' (DUL 467).

- Hapax Legomenon in a rather problematic context: hm brky tkšd r'umm ' $n k \underline{d d}$ 'aylt 'does not it crave the pool like wild bulls, the spring — like a herd of deer' (1.5 I 16-17). ${ }^{54}$

- Akk. kašādu 'to reach, to arrive' (AHw. 459, CAD K 271).

$\boldsymbol{\nabla}$ Akk.-Ugr. $* k \check{s} d$ (or $* k \hat{s} d$ ) "to reach' ${ }^{55}$ has no clear cognates elsewhere in Semitic. Of some interest may be Arb. kāšid- 'one who earns, obtains much' (LA 3 466), semantically remarkably similar to some of the prominent meanings of Akk. kašādu ('to obtain', 'to get hold', 'to conquer').

13. $\boldsymbol{k} \boldsymbol{b}$ ' 'to summon, to invoke' (DUL 690).

- Reliably attested in 1.161:9-10: $\mathrm{kr}$ 'itm rp'i 'ars $k b^{\prime} \mathrm{itm}$ ḳbs ddn 'you have summoned the $R p^{\prime} u m$ of the Earth, you have invoked the congregation

${ }^{53}$ Arb. hatt- 'line, streak, stripe' adduced in DUL 414 with reference to Lane 759 is semantically remote, being probably derived from the verbal root htt 'to make a mark upon the ground', which is further related to Akk. hatătu 'to make a ditch, to excavate' (CAD H 152), Syr. hat 'effodit' (LSyr. 226), JBA huttt 'to dig out' (DJBA 449), possibly Tna. hațät bälä 'to scratch' (TED 299).

${ }^{54}$ Cf. PARdeE 1997:265, Tropper 2000:794.

${ }^{55}$ The semantic overlap between Akkadian and Ugaritic is, of course, far from complete. 
of $D d n{ }^{\prime} .{ }^{56}$ Another possible attestation adduced in DUL is $k b^{\prime} a t$ in 1.6 VI 40 (heavily broken context).

- Akk. kabû 'to say, to tell, to speak, to decree' (AHw. 889, CAD Q 22).

- The origin of Akk.-Ugr. *kb $/ * k b y^{57}$ is uncertain. Any connection with Hbr. $k b b$ 'to curse, enchant' (HALOT 1060), Tgr. käbbä 'to contemn, to revile, to ignore' (WTS 249), Tna. käbäbä 'to mock, to deride, to scorn' (TED 980)?

14. $k r d$ 'hero, powerful one' (DUL 709).

- Attested as an element of B'l's title 'al'iy $\mathrm{krdm}$ 'the most powerful of

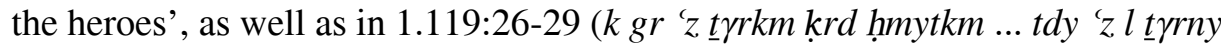
krd [l] hmytny 'when a mighty one attacks your gates, a valiant one your walls, (you will say) "if you throw away the mighty one from our gates, the valiant one from our walls..."').

- Akk. kardu 'heroic, valiant', karrādu 'hero, warrior', kurādu id. (AHw. 903, 905, 928, CAD Q 129, 140, 312).

$\nabla$ There is no reliable cognate for Akk.-Ugr. *krd 'to be heroic'. Could one tentatively compare Arb. $q d r$ 'to have power or ability to do smth.' (Lane 2495) with metathesis? Also of interest is Tna. kärrädä 'to refuse to agree or listen; to be stubborn, argue, to persist in wanting to overcome so.; to be rival, to quarrel with each other' (TED 949).

15. $l s m$ 'to run, to hurry', $l s m$ 'swift', $l s m t$ 'haste, alacrity', $m l s m$ 'race?' (DUL 504-505, 558).

- The verb $l s m$ and its nominal derivates are known from several reliable attestations: 'my p'nk tlsmn 'my twth 'šdk 'let your feet run to me, let your legs hasten to me' (1.3 III 19-20), ymșhn k lsmm 'they trample? each other like the swift ones ${ }^{58}$, (1.6 IV 20-21), kym 'il b lsmt 'those who assist 'il with alacrity'

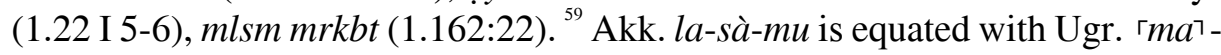
al-sà-mu in the lexical list (Huehnergard 1987:143).

${ }^{56}$ Or 'you are summoned ... you are invoked' (cf. BORDREUIL-PARDEE 1991:154-157, del Olmo Lete 2004:193-194, Pardee 1997:357).

${ }^{57}$ The underlying root *kby for Akk. $k a b \hat{u}$ has been advocated in recent studies on Sargonic Akkadian because of the orthographic alternation $i k$-BÍ [yiḳbi] 'he said' vs. $\grave{e}-k a ́$-BI [yekabbe] 'he says', which makes better sense if these forms are reconstructed as *yikbiy vs. *yikabbay (SOMMERFeld 1999:20, as well as HASSELBACH 2005:41-42, who deals specifically with the implications of this phenomenon for the etymological comparison under review).

${ }^{58}$ Presumably, horses (cf. PARDEE 1997:272).

59 'Coureurs de chars' according to PARDEE 2000:895. 
- Akk. lasāmu 'to run fast' (AHw. 538, CAD L 104).

จ Akk.-Ugr. * $l s m$ 'to be swift' lacks etymological parallels.

16. mnd ' 'perhaps' (DUL 561).

- Attested in 1.16 II 24 ( $m n d^{\prime} k r t m \gamma[y]$ 'perhaps $K r t$ has already depart-

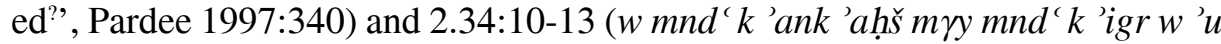
'ig $r]$ ' $m$ šps 'perhaps I will hurry to come, perhaps I shall lodge here or I shall lodge with the Sun').

- Akk. minde 'perhaps' (CAD M 283 , AHw. 655).

$\nabla$ While formally or semantically similar lexemes are attested more or less throughout WS - Hbr. maddūa' 'why?' (HALOT 548), Off. Arm. md'm 'something' (DNWSI 598), Gez. 'əndā $i$ 'perhaps' (CDG 28), Soq. 'ádạ̣ 'perhaps' (LS 53) - it is only Ugr. mnd' that matches Akk. minde exactly in both form and meaning. ${ }^{60}$ The most reliable reconstruction of the original shape of this particle is *mina 'ìda' 'what I know?' (AHw. 655, Tropper 2000:146).

\section{7. $\boldsymbol{n}$-dd 'to stand' (DUL 620).}

- Most of the relevant examples are listed under the meaning (3) 'to prepare, hurry, launch oneself' (lagerly based on Pope 1947 and Tropper-Verreet 1988:346347). By far the most transparent are the passages where $n$ - $d d$ is paralleled by (or

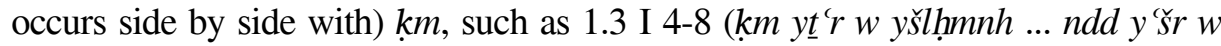
yškynh 'he arises, prepares, and gives him food ... he arises, serves and gives him drink', Pardee 1997:250) and 1.4 III 12-13 (ydd w yḳlșn yḳm $w$ ywptn 'he stood up and scorned me, he arouse and spat on me'). Also significant is 3.9:12-14: 'al ydd $m t$ mrzh w yrgm 'let no man of the association stand up and say'.

- Akk. izuzzu 'stehen' (AHw. 408).

$\checkmark$ Parallels to Akk. izuzzu elsewhere in WS are restricted to a few hypothetic remnants in Hebrew. Post-biblical zwz 'to move, to go away, to depart' (Ja. 385) is well compatible semantically ${ }^{61}$ and has indeed been compared with both izuzzu and $n$-dd ever since Poebel 1939:182-185 (v. most recently Huehnergard 2002:177-178), but one can only wonder how such a (presumably, very archaic) root could survive and even be commonly used in post-Biblical lan-

${ }^{60}$ The semantic difference between Akkadian and Aramaic has been aptly observed by KAUFMAN (1974:72).

${ }^{61}$ The semantic ambiguity of the concept 'to stand' - from the most stative 'to be still, motionless' to the most dynamic 'to arise for action' - is well illustrated by the usage of the Hebrew verbs $k w m$ and ' $m d$ (BDB 877, 763). Cf. also PoEBEL's penetrating remarks in 1939:184. 
guage without leaving a minor trace in its more ancient strata. ${ }^{62}$ Biblical maz $\bar{u} z \bar{a}$ 'door-post' is more feasible as a cognate (Poebel 1939:186-189), but the possibility of an Akkadian loanword (rejected by Poebel and, recently, Mankowski 2000:85) cannot be entirely discarded. Even if real, these sparse remnants would contrast sharply with the basic status of $n$ - $d d$ in Ugaritic.

18. ngr, ngrt 'herald' (DUL 623).

- $\quad$ Attested as a divine epithet: $\check{s} m^{\prime} l n g r$ 'il 'il[šs] 'ilš ngr bt bl $l$ w 'at th ngrt 'ilht 'listen, o herald of 'il, 'il[šs], 'il[šs], herald of the house of $B l$, and your wife, the herald of the goddesses' (1.16 IV 8-11). This widely accepted interpretation of $n g r$ and $n g r t$ (e. g., Pardee 1997:623) seems superior to *naggār- 'carpenter' (Huehnergard 1987:94). ${ }^{64}$

- Akk. nāgiru 'herald', nāgirtu id. (AHw. 711, CAD N 1115 ).

$\nabla$ The origin of Akk.-Ugr. nāgir- 'herald' is uncertain. The Akkadian lexeme is hard to separate from Sum. nimgir with the same meaning, and a borrowing from Akkadian to Sumerian appears more likely than vice versa (Edzard 1981:284-285, Steiner 2003:634, Sassmannshausen 1995:91-92, contra Sommerfeld 2006:64). The Akkadian term must then go back to a non-attested *nagāru 'to announce', ${ }^{65}$ in its turn likely related to Gez. nagara 'to say' and its Ethiopian cognates (so AHw. 710, CDG 392, Sanmartín 1991:197). Huehnergard's assertion "the word nāgiru "herald" is not attested in any Semitic language other than Akkadian" (1987:94) is nevertheless correct (contra Sanmartín).

19. mmrt 'splendour' (DUL 632).

- Hapax Legomenon in 1.108:24-25, in a series of divine attributes ( $z k$ dmrk l'ank htkk nmrtk' 'your strength, your protection, your power, your sovereignty?, your splendour').

${ }^{62}$ Poebel's comparison is emphatically rejected (unfortunately, with no argument whatsoever) in VON SODEN 1952:169.

${ }^{63}$ As one can judge from the examples collected in DUL 702, in the extant Ugaritic corpus $\mathrm{km}$ is probably no more frequent than $n-d d$. Moreover, $n-d d$ is once attested in a non-literary text, whereas $\mathrm{km}$ seems to be restricted to the literary corpus. All this means that my decision to treat $\mathrm{km}$ as the basic term with the meaning 'to stand' in Ugaritic (KogAN 2006a:442) was probably erroneous. The exclusive Ugaritic-Akkadian isoglosses in Swadesh wordlist (such as 'bird', 'breast', 'cloud') can thus be supplemented by one more reliable example.

${ }^{64}$ Huehnergard's reference to "the context of building a house" is unclear to me.

${ }^{65}$ Possibly preserved in nugguru 'to denounce' (CAD N $\mathrm{N}_{2} 313$ ) as well as in its nominal derivates munaggiru 'informer' (CAD $\left.\mathrm{M}_{2} 198\right)$ and taggirtu 'denunciation' (CAD T 38). 
- Akk. namurratu 'numinous splendour emanating from gods' (AHw. 730, CAD N 1 253).

$\boldsymbol{\nabla}$ An Akkadian loanword in Ugaritic postulated in Pardee 1988:115 is quite likely. Bulakh (2005:196-198) suggests, nevertheless, that the Akkadian and Ugaritic terms are rather related as cognates ${ }^{66}$ and go back to PS * $n m r$ 'to be brilliant', presumably attested also in Arb. namir-, namīr- 'pure, clean' (LA 5 276).

20. $\boldsymbol{n} \check{\boldsymbol{s}}-\boldsymbol{m}$ 'people, men' (DUL 649).

- Reliably attested in epics and an incantation: 1.3 III 27-28 ( $\mathrm{rgm} \mathrm{l}^{\mathrm{t}} \mathrm{t}$ ' $n \check{s} m$ w l tbn hmlt 'arș 'a matter which people do not know, the multitudes of the land do not understand'), 1.4 VII 49-52 ('ahdy $d$ ymlk 'l 'ilm d' ymr'u 'ilm $w$ $n \check{s} m d y \check{s} b$ [ ] hmlt 'arș 'I am the only one who rules over the gods, who fattens gods and men, who satiates the multitudes of the earth), 1.6 II 17-19 (np ̌s hsrt bn nšm npš hmlt 'arș 'my appetite lacked men, my appetite — the multitudes of the earth'), 1.17 VI 45 (n'mn 'mk nšm 'good and strong among men'), 9.435:910 ( $h w t r \check{s}^{\prime} h w t$ bn nšm 'the word of a wicked one, the word of (any) man'). The basic status of $n \check{s}-m$ is confirmed by the equation of its syllabic equivalent $\ulcorner n a\urcorner$ $[\check{s}] u-\ulcorner m a\urcorner$ with $\mathrm{U}[\mathrm{N}]$ in the lexical list (Huehnergard 1987:155).

- Akk. $n i \check{s}-\bar{u}$ 'mankind, human beings, people' (AHw. 796, CAD N 2 283).

$\boldsymbol{\nabla}$ Throughout WS, Ugaritic $n \check{s}-m$ is the closest approximation to Akk. $n i \check{s}-\bar{u}$ both formally (external masculine plural) and semantically ('men', 'people'). The complex etymological background of these terms ${ }^{67}$ cannot be discussed here in its entirety, but if structurally identical CS terms for 'women' (Hbr. $n \bar{a} \check{s}-\bar{i} m$, Syr. ně̌š-e, Arb. nis-ūna, HALOT 729, LSyr. 450, LA 15 374) indeed represent a semantic narrowing of an original meaning 'people' ${ }^{68}$, the fact that this isogloss is not shared by Ugaritic ${ }^{69}$ becomes all the more significant.

${ }^{66}$ Bulakh emphasizes correctly that the Akk. namurratu and related lexemes with - $m$ - cannot be immediately derived from nawāru 'to shine' (cf. EDZARD 1994).

${ }^{67}$ Notably, their relationship to PCS * 'inš- 'man' and related CS terms.

${ }^{68}$ As is widely acknowledged (BAUER-LEANDER 1927:617, DUL 650, HuEHNERGARD 1987:77, KREBERNIK 1985:54). The archaic nature of the $a$-vocalism in Hebrew is, contra BAUER-LEANDER 1927:617, reaffirmed not only by Ugr. $\ulcorner n a\urcorner-[\check{s}] u-\ulcorner m a\urcorner$, but also by the Akkadogram $N A-S E_{11}$ in Ebla (KREBERNIK 1985:54). The vocalic difference between Akkadian, Arabic and, probably, Syriac on the one hand and Hebrew, Ugaritic and Eblaite on the other remains enigmatic. Arb. $n \bar{a} s$ - and Arm. $n \bar{a} \check{s} \bar{a}$ 'people' are not to be directly associated with any of the aforementioned forms as they almost certainly go back to prototypes with 'V- ('unās-, ' 'änāš $\bar{a}$ ). Also the long $\bar{a}$ in Arabic and Aramaic is not compatible with the short $a$ in Hebrew (st. constr. nə̌̌ $\bar{e}$ ).

${ }^{69} \mathrm{Cf}$. the regular (non-suppletive) plural of 'att 'woman' in 4.349:2 ('arb' 'att 'four women', DUL 130). The same is true of ESA, where '( $n) \underline{t} t$ has a variety of plural forms (Sab. '(n)t $\underline{t}$, 'n $\underline{t}$, ' $n \underline{t}$, SD 7; Min. ' $n \underline{t} h t, \mathrm{LM} 6)$ and $* n \mathrm{~V} \check{s}$ - is not attested at all. 
21. phd 'a yearling lamb' (DUL 669)

- Hapax Legomenon in 1.17 V 16-19: 'db 'imr b phd l npš ktr w hss l brlt hyn $d$ h $r^{\check{s}}$ 'she prepared a lamb from the flock, for the throat of Ktr $w$ hss, for the gullet of Hyn $d$ hrš' (Pardee 1997:346). This interpretation of phd remains the most likely one notwithstanding a few obvious difficulties (notably, the absence of collective meaning for Akk. puhāadu).

- Akk. puhādu 'lamb, young male sheep' (AHw. 875, CAD P 476).

$\checkmark$ Akk.-Ugr. *puhād- 'lamb; flock' has no cognates elsewhere in Semitic.

22. $s$ 'in 'edge, hem' (DUL 751).

- Hapax Legomenon in 1.6 II 9-11, meaning reliably established from context: t'ihd $m t b$ s'in lpš tšșkn $[n] b$ ks 'all 'she took $M t$ by the edge of his garment, she seized him by the hem of his mantle'.

- Akk. sūnu 'a cloth trimming' (CDA 328). More traditional interpretations found in CAD S 388 ('a piece of clothing or part thereof') and AHw. 1059 ('ein Tuch oder Binde') are likely to be rejected (Moran 1983). ${ }^{70}$

$\nabla$ There is no cognate for Akk.-Ugr. *su'n- 'hem'. According to AHw. 1059, the Akkadian term is borrowed from Sum. $\mathrm{t}$ ù $\mathrm{n}$, but this is difficult to reconcile with the Ugaritic evidence (let alone the internal Akkadian difficulties outlined in Moran 1983).

23. $\boldsymbol{t b}$ ' 'to go, leave, depart' (DUL 857).

- Passim in the Ugaritic corpus.

- Akk. tebûu 'to get up, to rise; to set out, to depart, to leave' (AHw. 1342, CAD T 306).

$\nabla$ Akk.-Ugr. * $t b$ ' 'to set out, to depart' are probably related to Arb. $t b$ ' 'to follow' (Lane 293) ${ }^{71}$, but the semantic gap underlying this comparison contrasts sharply with the virtual semantic identity between Akkadian and Ugaritic.

${ }^{70}$ The most exact semantic match for the Ugaritic lexeme is Durand's 'ourlet' (2000:586, with more details in 2009:93-95).

${ }^{71}$ Mhr. $t \bar{u} b a$, Jib. $t \bar{e}$ ' 'to follow' (ML 399, JL 269) are probably Arabisms. In CDG 569, Gez. $t a b^{\prime} a$ 'to be brave, to be manly' and its ES cognates are tentatively compared to Akk. teb $\hat{u}$ 'to

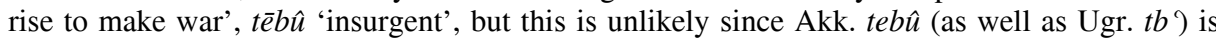
primarily a verb of movement whose military connotations are at best secondary. Contra DUL 857 and LSyr. 814, Syr. $t b a$ ' 'ursit, institit, pressit' and its Aramaic cognates are not related to

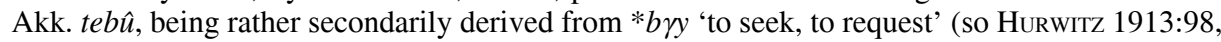
ZABORSKI 1971:58). 
24. tmn 'foundation, frame' (DUL 871).

- Hapax Legomenon in 1.2 IV 17-18: l tnүșn pnth l ydlp tmnh 'his knuckles did not buckle, his frame did not break up'. It seems preferable to identify tmn in this passage with Akk. temmennu 'foundation' (CAD T 337) ${ }^{72}$ separating it from Hbr. təmūna 'form, manifestation' (HALOT 1746) and its presumable Ugaritic cognate tmnt.

- Akk. temmennu 'foundation' (AHw. 1346, CAD T 337).

$\checkmark$ Akk. temmennu is usually thought to be borrowed from Sum. t e m e $n$ (Lieberman 1977:502), but cf. Civil 2007:27 where it is listed among early Semitic loanwords in Sumerian.

25. trbș 'yard, reserve' (DUL 620).

- Hapax Legomenon in 1.14 III 24-25: mrkbt b trbs 'a chariot from the

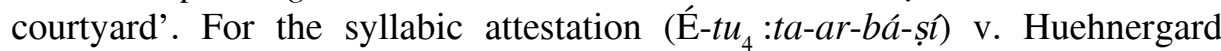
1987:176.

- Akk. tarbāṣu 'pen (for cattle, rarely for sheep and goats, horses), enclosure, courtyard' (AHw. 1327, CAD T 217).

$\boldsymbol{\nabla}$ Akk.-Ugr. *tarbāṣ- 'enclosure, yard' goes back to PS * rbṣ̂ 'to lie down, to rest (mostly of animals)' (HALOT 1181).

26. trb 'to get married' (DUL 878).

- Both the verbal root and its nominal derivates are widely attested: 1.14 I 12-14 ('att șdkh l ypk mtrht yšrh 'att trh $w$ tb't 'he did not obtain his lawful wife, no legitimate spouse, he married a wife but she went away'), 1.23:64-65 ( $y$ 'att 'itrh y bn 'ašld 'o wives whom I married, o sons whom I begot'), 1.14 II 47-50 (yș'i trh hadt yb'r l țn 'atth lm nkr mddth 'let the newly married leave his wife to someone else, his beloved one to a stranger'), 1.111:20 (trht t'arš 'the bride-price that you will request'), and passim in 1.24.

- Akk. terhatu 'bridewealth' (AHw. 1348, CAD T 350).

$\nabla$ The origin of Akk.-Ugr. *trh 'to pay a bride-price, to get married is uncertain'. ${ }^{73}$ Possible WS attestations of *trh outside Ugaritic are problematic: the meaning of the Phoenicial priestly title mtrh ̌ štrny is disputed (cf. DNWSI 710, Krahmalkov 2000:390), whereas Sab. trh, sometimes understood as 'redemption-price' (cf. SD 148, Biella 536) is phonologically unsuitable (Sab. ha vs. Akk. and Ugr. ha).

${ }^{72}$ With De Moor 1971:137 and contra Dietrich-Loretz 1978, PARdeE 2000:884-885.

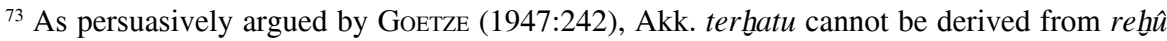
'to copulate, to inseminate', as it used to be supposed in earlier studies quoted ibid. 


\section{CONCLUSIONS ${ }^{74}$}

\subsection{Ugaritic as a Canaanite language - the lexical evidence}

The lexical evidence dealt with in this article is substantially different from the Swadesh wordlist analyzed in Kogan 2006a. Since the impact of this difference is mainly negative, it seems appropriate to outline the deficiencies of the new evidence in greater detail before proceeding to its more positive outcome.

1. Swadesh wordlist is restricted to the most fundamental lexical features whose relevance for genealogical classification is potentially high because of their clear-cut semantic shape and slight probability of borrowing. Lexical features discussed in the present article have no such restrictions: some of them belong to less basic, more culture-bound semantic fields, such as social hierarchy and professions (*'Vby-ān- 'poor', No. 2; *'adān- 'lord', No. 5; *ha $a(r)$ raš- 'artisan', No. 36; *kbs 'to wash clothes', No. 38; *yǩs 'to hunt with a snare', No. 73), materials, tools and artifacts (*'Vny(-at)- 'ship', No. 12; *'Vpn- 'wheel', No. 13; *bardill- 'iron', No. 22; *nVtk- 'weapon', No. 48; *rVt-t- 'net', No. 55; *ta' $r$ - 'sheath', No. 64; *tulhān- 'table', No. 68; *ya' $r$ I*ta' $r$ - 'knife, razor', No. 71), construction and architecture (*'arubb-at- 'skylight', No. 15; * 'ìr- 'city', No. 18; *gagg- 'roof', No. 25; *hāmiy-(a)t- 'wall', No. 35), agriculture (*dagan- 'grain', No. 24; *gin-t- 'wine or olive press', No. 28; *kussam-t- 'spelt', No. 39; *pVt-t 'flax', No. 53; *s VmVk- 'raisin', No. 58), abstract concepts and intellectual activities (*'ān- 'vigor, wealth', No. 10; *'awn- 'misfortune', No. 11; *'aps- 'extremity', No. 14; *hamull-at'crowd', No. 31; *paš - 'crime', No. 52; *tamūn-at- 'shape, form', No. 66; *tūšiyy-at- 'success', No. 67; *wsr/*ysr 'to teach, to instruct', No. 70; *yapịh'witness', No. 74).

2. In the framework of Swadesh wordlist, functional equivalence between the terms under comparison is of paramount importance: presence of this or that root in a given pair of Semitic languages is not relevant unless both lexemes in question can be shown to function as the basic exponents of the respective concept. The present investigation, on the contrary, accumulates all exclusive isoglosses between Ugaritic and Canaanite independently of their functional status. Thus, a given Ugaritic lexeme can be attested as a margi-

\footnotetext{
${ }^{74}$ Unless specified otherwise, the numbers in the concluding section refer to the lexical entries presented in the author's article published in the preceding issue of Sefarad (70/1).
} 
nal, non-basic word, whereas its Canaanite cognates clearly enjoyed the basic status, like * $d b r$ 'to say' (No. 23) or *harr- 'mountain' (No. 32). ${ }^{75}$ The reverse is also possible, as shown by *yapịh- 'witness' (No. 72).

Significantly, the traditional, "narrow" Canaanite is sometimes divided along the same lines. Thus, a few specific lexical features prominent in Hebrew are marginal in both Ugaritic and Phoenician: * ' $r$ - 'city' (No. 18), * ‘̌s $y / *$ ' $\hat{s} y$

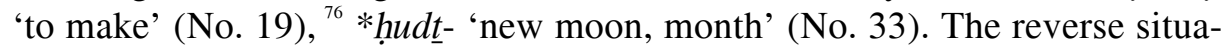
tion (a root marginal in Hebrew, but basic in both Ugaritic and Phoenician) can be illustrated by *bād- 'by, at, from' (No. 20) and *šyt 'to put' (No. 63), perhaps also *nub-t- 'honey' (No. 45). ${ }^{77}$ The only isogloss separating Hebrew and Ugaritic from Phoenician is the broad use of the negative particle * 'ayn(Ginsberg 1970:109).

3. Lexemes accepted for comparison in Swadesh wordlist have to be well attested in semantically unambiguous contexts, which assure their basic status independently of etymological considerations. ${ }^{78}$ Hapax Legomena and other rare words whose exact meaning (let alone functional status) cannot be established contextually are preferably to be left out of consideration. In the present article, on the contrary, a few Hapax Legomena have been admitted: * an 'strength' (No. 10), *'aps- 'extremity, end' (No. 14), *dagan- 'grain' (No. 24), *gyl 'to rejoice' (No. 26), *gV̌̌m- 'rain' (No. 28), *lyn 'to sleep, to stay the night' (No. 40), *matt- 'down'/*mVttt-at- 'bed' (No. 42), *paš - 'crime, transgression' (No. 52), *rVt-t- 'net' (No. 55), * šns 'to gird' (No. 61), *ta 'r'sheath' (No. 64), *tūšiyy-at- 'success' (No. 67).

4. Quite often, the diachronic background of this or that CC lexeme cannot be elicited, which makes impossible to consider it a shared innovation. And conversely, some of the typically Canaanite words do have cognates with more or less the same meaning ${ }^{79}$ somewhere else in CS or WS: *' $d m$ 'to be

75 Presumably also *gV̌̌m- 'rain' (No. 28) and *naḥaš- 'snake' (No. 47). Since no Phoenician exponents are available for these concepts, one cannot exclude that the functional status of these lexemes in Hebrew and Phoenician was not identical (in which case they would rather belong with the isoglosses discussed in the next paragraph).

${ }^{76}$ Ginsberg (1970:111) considers this lexeme to be "the simplest mark" by which his "Hebraic group" can be distinguished from other Canaanite languages as well as from the rest of Semitic. The latter is not the case in view of the broad presence of ' $s_{1} y$ in ESA.

${ }^{77}$ Phoenician evidence for *nub-t- is scarce, but *dib̌s- is not attested at all.

${ }^{78}$ Needless to say, for a dead language with a restricted textual corpus even such contexts have no absolute value.

${ }^{79}$ Some of them even the same basic status. 
red' (No. 3), *'adam- 'man; mankind' (No. 4), *'irr- 'city' (No. 18), * šy/* 'sy 'to make' (No. 19), *sbb 'to turn' (No. 56), *spr 'to count' (No. 57), *yayn'wine' (No. 72). Evidently enough, these lexemes, too, cannot be regarded as Canaanite innovations, but only as specific, less trivial retentions from PCS or PWS.

These deficiencies are weighty enough to be taken seriously by everybody willing to assess the lexical proximity between Ugaritic and Canaanite. Nevertheless, they are not sufficient to overshadow the positive aspects of the present lexical inquiry.

1. Perhaps the most striking result of our investigation is the extraordinary high number of exclusive lexical isoglosses between Ugaritic and Canaanite. There is virtually nothing to compare with 78 exclusive (or, rarely, quasiexclusive) lexical features shared by Ugaritic with Hebrew and/or Phoenician - contrast 18 exclusive isoglosses between Ugaritic and Arabic or 26 between Ugaritic and Akkadian, let alone the meager five exclusive lexical features shared by Ugaritic with Aramaic, its potentially closest NWS relative. With all possible limitations in mind, this huge amount of exclusive lexical features cannot be dismissed as diachronically meaningless. ${ }^{80}$

2. Many of the relevant lexemes do belong to the most basic semantic strata: *'dm 'to become red' (No. 3), *'adam- 'man; mankind' (No. 4), *'hb 'to love' (No. 7), *'ayn- 'there is not' (No. 9), * 'sy/* 'sy 'to make' (No. 19), *bād- 'by, at, from' (No. 20), *dbr 'to say' (No. 23), *gašm- 'rain' (No. 28), *hlm 'to strike' (No. 30), *harr- 'mountain' (No. 32), *lyn 'to sleep, to stay the night' (No. 40), *na'r- 'boy, lad' (No. 43), *nub-t- 'honey' (No. 45), *naḥaš- 'snake' (No. 47), * šyt 'to put' (No. 63), *tawk- 'midst' (No. 65), *yr' 'to be afraid' (No. 76), *yṣk 'to pour' (No. 77), *ytn 'to become old' (No. 78). It is thus fair to claim that CC isoglosses are not restricted to the superficial layers of the cultural vocabulary.

3. The proportion of Hapax Legomena among the relevant Ugaritic lexemes is by no means high (12 out of 78). Our conclusions are thus based on well attested lexemes and not on a few exotic occasionalisms. Comparison with Ugaritic-Arabic isoglosses is instructive in this respect: among 18 exclusive lexical features shared by Ugaritic with Arabic, Hapax Legomena are no less than 13.

${ }^{80}$ In other words, as far as genealogical affiliation of Ugaritic is concerned, it is not possible to find any remotely comparable number of "roots and words in subsets of languages that would indicate other subgroupings" as predicted by HuEHNERGARD (2005:190, cf. HASSELBACHHUEHNERGARD 2007:420). 
4. For more than $20 \mathrm{CC}$ lexemes, the path of semantic or formal innovation can be plausibly reconstructed: *'ab(b)ir- 'bull; horse' (No. 1), *'Vby$\bar{a} n$ - 'poor' (No. 2), *'ayn- 'there is not' (No. 9), *'Vny(-at)- 'ship' (No. 12), *'Vpn- 'wheel' (No. 13), *bād- 'by, at, from' (No. 20), *bkt 'to look for' (No. 21), *gyl 'to rejoice' (No. 26), *hudt- 'new moon, month' (No. 33), *hāmiy-(a) t- 'wall' (No. 35), *ha(r)raš- 'artisan' (No. 36), *kbs 'to wash clothes' (No. 38), *kussam-t- 'spelt' (No. 39), *lyn 'to sleep, to stay the night' (No. 40), *nub-t'honey' (No. 45), *naḥaš- 'snake' (No. 47), *pa'm- 'time' (No. 49), *ș VmVk'raisin' (No. 58), *saday- 'cultivated field' (No. 59), *šyt 'to put' (No. 63), *ya 'r-/*ta 'r- 'knife, razor' (No. 71). Given the fact that — at least in Semitic — the origin of "new lexemes" " ${ }^{81}$ can rarely be established even hypothetically, the significance of this proportion can hardly be overestimated.

In view of the evidence collected and analyzed in the present article, a close association between Ugaritic and Canaanite (not fully apparent as long as the inquiry was restricted to the concepts of Swadesh wordlist) becomes a feasible probability. To put it differently, if there is any subdivision of Semitic with which Ugaritic has ever been specially connected, this subdivision is of necessity the Canaanite group. This conclusion itself is not new. What is innovative is rather the vast body of supporting evidence, which will probably make the Canaanite hypothesis more credible than the somewhat impressionistic statements of my predecessors. ${ }^{82}$

The Canaanite affiliation of the Ugaritic vocabulary quickly prompts a few fundamental questions of genealogical, geographic and historical order.

${ }^{81}$ To be sure, the situation with "new morphemes" (i. e., morphological innovations used in the subgrouping procedure) is exactly the same if not worse.

${ }^{82}$ Such as GREENFIELD 1969:98 ("but the bulk, the great bulk of the vocabulary of Ugaritic, when not gemeinsemitisch ... has its strongest links with Canaanite") or TROPPER 1994:351 ("it is an undisputable fact that the great majority of the Ugaritic lexicon (about 70\%) and especially the basic vocabulary of Ugaritic is attested in the Canaanite dialects with the same or at least similar meaning". Tropper gives no single example of a common Ugaritic-Canaanite lexical feature, nor does he specify the source of his statistics. Greenfield refers to "the common words for table, roof, window, fish" without mentioning any concrete lexical form, whereas at least the first three overtly cultural - concepts are by no means the best available illustrations of what the common words and the bulk of the vocabulary of Ugaritic actually are. One can easily understand why these and similar statements, in spite of being even if essentially correct, did not produce much confidence, especially among scholars a priori skeptical about the classificatory value of the basic vocabulary. The same applies to GinsBerg 1970:103 where 'roof', 'window' and 'table' are supplemented by * $y \underline{t} n$ 'to be old (of things)', * gřs 'to drive out' and * $\underline{d} k n$ 'to be old (of people)'. That the latter feature is "confined to the Canaanite languages" is, moreover, incorrect (KogAn 2006a:432). 
By far the most important problem is how the very designation "Canaanite" should be understood. As we have just seen above, some of the most conspicuous lexical isoglosses labeled "Common Canaanite" in this article fully affect Ugaritic and Phoenician only, their presence in Hebrew being quite marginal. And conversely, some of the typically Hebrew lexemes are only sporadically attested in Ugaritic and Phoenician. As long as both Phoenician and Hebrew are thought to be legitimate representatives of the Canaanite Sprachtypus (which is the common opinion), one is forced to conclude that even within this "classical" or "narrow" Canaanite there are two different, only partly overlapping, bundles of specific lexical features - a Southern one and a Northern one. The fact that both types of lexical features are to some extent present over the whole Canaanite area can be explained in two different ways. The relevant isoglosses could have emerged in an incipient form already in Proto-Canaanite, but their subsequent development - from marginal to highly prominent - was different in the North and in the South. Alternatively, two independent focuses of lexical innovations can be postulated, influencing each other via geographic diffusion.

Evidently enough, it is the Northern bundle with which Ugaritic is particularly closely associated. The easiest way to explain this association is, of course, the geographic proximity between Ugarit and Phoenicia as opposed to more southern and more inward areas of Canaan. It is this geographic solution that is usually accepted by those Semitists who do not consider lexical evidence as a reliable tool of genealogical sub-grouping, but are nevertheless reluctant to disregard completely some of the most striking lexical coincidences. $^{83}$

However, also a genealogical hypothesis envisaging a diachronic unity of Phoenician and Ugaritic within the Canaanite group is worth considering. The vocabulary of such a "Phoenic group," postulated without hesitation in Ginsberg's brilliant summary description of NWS (1970), can be characterized — both positively and negatively — by several important isoglosses. From among the features collected in the present article, note ${ }^{+*} b \bar{a} d$ - 'by, at, from' (No. 20), ${ }^{+*} \check{s}_{y} y t$ 'to put' (No. 63), ${ }^{+*} n u b-t$ - 'honey' (No. 45) and ${ }^{-*}$ 'i $r$ 'city' (No. 18), ${ }^{-*} \check{s} y$ ‘to make' (No. 19), ${ }^{-* h u d t-~ ' n e w ~ m o o n, ~ m o n t h ' ~(N o . ~ 33) . ~}{ }^{84}$ A closer inquiry into Swadesh wordlist will supplement this list with ${ }^{+*} p a$ ' $m$ I*pa 'n- (-*rVgl-) 'foot' (Ginsberg 1970:105, Kogan 2006a:458), ${ }^{+*} n$ 'm (-*tyb) '(to be) good' (Kogan 2006a:454), +*ytn (-*ntn) 'to give' (Ginsberg 1970:105,

${ }^{83}$ E. g. TROPPER 1994:351-353.

${ }^{84+}$ means "extensive use, basic status", - means "marginal use, non-basic status". 
Tropper 1994:351), ${ }^{85}$ perhaps ${ }^{+*}$ ' $d r\left({ }^{-*} g d l\right)$ '(to be) big' ${ }^{86}$ Note, finally, a few other lexemes collected in Harris 1939:52, Ginsberg 1970:105, del Olmo Lete 1986:45-46, Tropper 1994:351 and Kogan 2006b:252: ${ }^{+*} k w n\left({ }^{-*} h w y\right)$ 'to be', +*harūṣ- (-* $\underline{\text { dahab-) }}$ 'gold', ${ }^{+*}$ 'alp- (-*tawr-, *-bakar-) 'bull, ox, cattle'.

A comprehensive diachronic assessment of the "Phoenic"/"Hebraic" lexical dichotomy - to one's utmost regret, fatally hampered by the severe shortage of Phoenician lexical material — is still to be carried out. One possible model of explanation has been briefly outlined above in connection with $* \check{s} y t$ 'to put'. The readiest interpretation of this peculiar case is that a highly innovative CC feature once affected (proto-)Hebrew, but then gradually receded, perhaps under a foreign influence. The same approach can be applied to several other examples adduced in the preceding paragraph: for 8 out of 13 basic concepts, the Hebrew equivalents are the same as in Aramaic (to some extent, also Arabic) in opposition to Ugaritic/Phoenician. Within such a paradigm, Ugaritic is to be regarded not just as Canaanite, but as Canaanite par excellence, ${ }^{88}$ whereas for Hebrew a kind of lexical "de-Canaanization" has to be posited.

${ }^{85}$ This is of course a formal (but still lexically determined) peculiarity.

${ }^{86}$ That ' $d r$ functioned as the basic term for '(to be) big' in Phoenician is likely. In Kogan 2006a:444, I tentatively accepted $r b$ as the main exponent of this meaning in Ugaritic, but the supporting evidence for this assumption was scarce. Now it seems that 'adr is at least no less likely to fill this semantic slot, especially in view of its wide presence in non-literary texts, notably in opposition to $d k$ (which, then, could be considered as the main exponent of the meaning 'small', with HuEHNERGARD 1987:39, TROPPER 1997:664-665 and contra KogAn 2006a:449-450): tn kndwm 'adrm $w$ kndpnt $d k$ 'two large $k n d w$-garments and one small kndpnt-garment' (4.4:2-3), yryt $d k[t]$

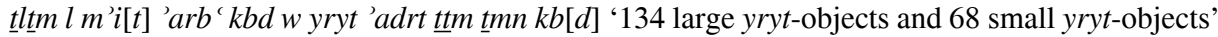
(4.411:3-8), 'att 'adrt 'grown-up' woman' passim in 4.102 (cf. Hbr. $g d l, g \bar{a} d \bar{o} l$ about age in BDB 152-153). The literary attestations do not provide any positive evidence for this hypothesis, but do not contradict it either. The precise meaning of the lexical entry $a$-du-rù (HUEHNERGARD 1987:104) can hardly be established (according to HuEHNERGARD 2008:388, the newly discovered Hurrian $a-m u-m i-i a-a \check{s}-\bar{s} e$ suggests, admittedly, the translation 'noble').

${ }^{87}$ In Ugaritic, 'alp (pl. 'alpm) was the basic designation of large cattle widely attested in a variety of contexts. The usage of $\underline{t} r$ is, conversely, restricted to the poetic corpus, whereas $b k r$ is attested only once. The Phoenician picture is almost exactly the same (' $l p$ common, $b k r$ rare, * ${ }^{s} r$ unattested), the Hebrew one is exactly the opposite ( $\check{s} \bar{r} r$ and $b \bar{a} k \bar{a} r$ common, 'äläp deeply marginal).

${ }^{88}$ With del Olmo Lete 1986 and, it seems, contra Liverani 1964:191, who believes that only late, non-literary varieties of Ugaritic documentation start to display Canaanite features. As far as I can see, the evidence collected in Liverani's study hardly ever corroborates this conclusion. Surprisingly enough, lexical evidence is not even mentioned in Liverani 1964.

${ }^{89}$ I am well aware that this model is not easily compatible with some crucial assumptions about the basic lexicon on which the present investigation is largely based (such as diachronic stability and resistance to borrowing). However, an instructive example pointing exactly in the same 
To what degree the lexical evidence for the "Phoenic" hypothesis is compatible with a variety of positive and negative morphological isoglosses between Ugaritic, Amarna Canaanite, Phoenician and Hebrew is (and will probably remain for quite a while) a debatable issue in Semitic diachronic linguistics. ${ }^{90}$

Another interesting problem is the chronological stratification of the lexicon within the linguistic history of Ugaritic. It has often been observed (Albright 1958:38, Held 1959:174-175, Haldar 1964:276-277, Liverani 1964) that both the grammar and the vocabulary of Ugaritic prose can be substantially different from the language of myths and epics. Can such differences be detected within the body of the evidence discussed in the present contribution? A positive answer would be of great importance for both genealogical and geographic dimensions as described above. On the one hand, some of the "incipient Canaanisms" could be not ripe enough to appear in the archaic poetry, but nevertheless flourish in the everyday prosaic speech. On the other hand, the poetic corpus could be too archaic to be affected by the hypothetic diffusion of the Southern Canaanite, "Hebraic" lexical features. Some evidence in favor of this hypothesis is indeed available: *dbr 'to say' (No. 23), *gV̌rm- 'rain' (No. 28), *harr- 'mountain' (No. 32), *naḥaš- 'snake' (No. 47), *ḥudt- 'new moon' (No. 33) are attested in letters, incantations, omens, rituals and other cultic texts, but not in myths and epics. ${ }^{91}$ But, in general, one has rather to agree with Greenfield

direction can be detected also in the realm of verbal morphology. As is well known, $t$-prefixation in the $3 \mathrm{~m}$. pl. of the prefix conjugation is one of the most salient peculiarities of both Ugaritic and Amarna Canaanite. This feature — no doubt a highly specific innovation with respect to PS *y- left virtually no trace in either Phoenician or Hebrew, which, for all practical purposes, are usually considered as linear descendants of the Canaanite linguistic varieties attested in the EA corpus. A non-motivated abandonment of such a marked innovation with a concomitant re-establishment of its diachronic forerunner (which, as common sense plainly suggests, must have been simply forgotten many generations ago!) looks an unexplainable mystery unless one suspects some sort of "de-Canaanizing" external influence.

${ }^{90}$ Thus, TROPPER (1994:352), after a penetrating acknowledgement of the lexical proximity between Ugaritic and Phoenician, emphatically denies the possibility "to subsume Ugaritic and Phoenician in one single subgroup of Canaanite" since "morphological differences between Ugaritic ... and all South Canaanite dialects ... still remain and should not be ignored". Not a single morphological difference of this kind can, however, be located on the pages of Tropper's contribution. Moreover, Tropper rejects as irrelevant virtually all such differences suggested in previous studies on the topic (e. g. Blau 1978:38-39, HueHnERGard 1991b:286), such as the Canaanite shift $* \bar{a}>\bar{o}$, the $\check{s}$-causative and the shift $* a>i$ in the first syllable of the suffix conjugation of the intensive and the causative stems.

${ }^{91}$ Perhaps $r i-i[g]-l u\left(\right.$ rather than $p^{\prime} n$ ) in the lexical list (HuEHNERGard 1987:176, 72) belongs 
(1969:98) that the Canaanite nature of the Ugaritic vocabulary is manifest in all of its chronological and stylistic strata.

\subsection{Exclusive lexical isoglosses between Ugaritic and Arabic: an evaluation}

18 exclusive lexical features shared by Ugaritic with Arabic give a fair account of the lexical proximity between these two languages. ${ }^{92}$ But the paucity of examples is not the only argument in this case. The immense majority of the relevant Ugaritic lexemes are Hapax Legomena —non-basic, functionally marginal lexemes preserved as rare poetic occasionalisms. That such words have no reliable cognates outside Arabic can be easily explained by the extraordinary richness of the Classical Arabic vocabulary accumulated in traditional lexicographic tools. Moreover, in the whole corpus of exclusive Ugaritic-Arabic lexical features there is not a single reliable semantic innovation. This is a telling witness of the archaic, conservative nature of the Ugaritic-Arabic lexical coincidences. To sum up: as long as basic vocabulary is considered to be of some relevance for linguistic subgrouping, the probability of a special genealogical relationship between Ugaritic and Arabic, still advocated in some recent studies on the topic, ${ }^{93}$ is close to zero. ${ }^{94}$

\subsection{Ugaritic and Akkadian: shared lexical archaisms or early loanwords?}

By their nature, exclusive lexical isoglosses between Ugaritic and Akkadian are fundamentally different from similarly exclusive matches between Ugaritic and West Semitic languages. Lexical features which Ugaritic shares with Hebrew, Aramaic or Arabic are potentially indicative of a closer genealogical proximity. For obvious reasons, no special genealogical relationship between Ugaritic and Akkadian is at all conceivable, which means that the lexical features under scrutiny cannot be shared innovations. But where do they come from? Theoretically, two explanations suggest themselves:

to the same group of "recent", "non-Canaanite" lexemes.

${ }^{92}$ Contra Healey (1995:82-84), a lexical investigation aiming at a meaningful pattern of genealogical subgrouping can by no means ignore such fundamental notions as exclusiveness of lexical isoglosses, functional equivalence between the lexemes under scrutiny, their innovative vs. conservative nature, let alone the frequency of their attestation and their philological reliability. Without a systematic application of these concepts, any crude statistics of lexical coincidences between Ugaritic and this or that Semitic language is deemed to be useless.

${ }^{93}$ Such as Kaye 1991.

${ }^{94}$ The same is obviously true of the Ugaritic-Aramaic genealogical proximity advocated in SEgERT 1965. 
1. non-trivial lexical retentions from Proto-Semitic, lost elsewhere in WS but preserved in Ugaritic because of its archaic character and/ or early written attestation

or

2. lexical borrowings from Akkadian into Ugaritic which did not penetrate into other WS languages, less affected by the influence of the cuneiform civilization.

In fact, there need not be one solution for the whole corpus of examples. While some cases are best explainable as shared archaisms, others can be more convincingly interpreted within the borrowing paradigm. ${ }^{95}$

The former solution is to be preferred when we are faced with lexemes belonging to more basic semantic strata and, therefore, unlikely to be borrowed: 'mr 'to look at' (No. 2), 'išd 'leg' (No. 3), 'rb 'to enter' (No. 6), $n$ - $d d$ 'to stand'

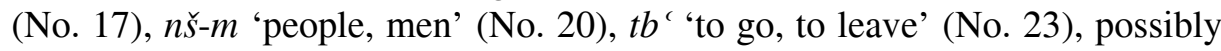
also ' $m$ k 'tough, strong' (No. 5), kms 'to buckle' (No. 11), kšd 'to search for,

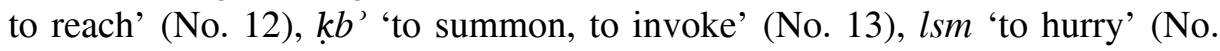
15), mnd ' "perhaps' (No. 16). Together with a few Akkadian-Ugaritic isoglosses from Swadesh wordlist ( 'ṣr 'bird', 'irt 'breast', 'rpt 'cloud', Kogan 2006a:456457), such lexemes may belong to a very ancient stock of Proto-Semitic vocabulary still preserved in Ugaritic, but lost or marginalized in WS languages with more recent textual documentation. ${ }^{96}$ Direct borrowing from Akkadian - at least in historical times ${ }^{97}$ — seems highly improbable in such cases.

${ }^{95}$ This dichotomy was clear already to HALDAR (1962:275): "there are a number of pure Akkadian loanwords in Ugaritic, and in other cases common Semitic words have the same meaning in Ugaritic and Akkadian in contradistinction to the other Semitic languages". This reasonable statement is followed by a very short list of randomly selected examples, none of which is explicitly attributed to any of the two aforementioned categories.

${ }^{96}$ One may be tempted to suppose (with Held 1959:174-175, Albright 1958:38, Liverani 1964) that, because of the archaic nature of Ugaritic myths and epics, many of the pertinent lexemes can be even more ancient than the tablets on which they are inscribed, thus reducing the chronological gap between Ugaritic and Akkadian and emphasizing the difference between Ugaritic and WS languages of the $1^{\text {st }}$ millennium (such as Hebrew). This hypothesis is plausible, although it fails to account for several common lexemes not restricted to the literary corpus (' $r b$ 'to enter', $n$ - $d d$ 'to stand', $t b$ ' 'to go, to leave', 's $r$ 'bird'). Besides, the extant non-literary texts in Ugaritic are by no means representative from the lexical point of view.

${ }^{97}$ The pre-historic situation might have been different, however, as will be surmised in the end of this subsection. An early presence of East Semitic linguistic varieties in Syria might be 
The second alternative brings us to the thorny problem of Akkadian lexical influences on Ugaritic, a problem which received surprisingly little attention from Ugaritological scholarship notwithstanding its obvious relevance. ${ }^{98}$ Even W. Watson's meticulous inquiry into foreign vocabulary of Ugaritic ${ }^{99}$ deals only with non-Semitic loanwords and excludes Akkadisms. It becomes less surprising, in such a context, that not a single lexeme from our list has been even tentatively qualified as an Akkadism by the authors of DUL.

As a systematic perusal of Watson's lists of non-Semitic loanwords in Ugaritic demonstrates, most of them are concentrated in political, administrative, economic and, to some extent, cultic contexts, where they usually designate more or less specific realia. ${ }^{100}$ A few Akkadian loanwords are certainly expected to appear in the same groups of texts and can indeed be detected on the pages of DUL, although more or less promising examples are surprisingly few in number: $m d$ 'an official' < mūdû (DUL 524, CAD M $\mathrm{M}_{2} 167$ ), ${ }^{101} \mathrm{mhr}$ 'price' < mahìru (DUL 539, CAD M 92), mnt 'recitation of spell, incantation' < minūtu (DUL 565, CAD M 2 98), nkš 'accounting, accounts' < nikkassu (DUL 631), ${ }^{102}$ $n p \check{s}$ 'red wool' < nabāsu (DUL 637, CAD N 121 ), rbṣ 'inspector' < rābișu (DUL 731, CAD R 20), ršy 'to receive, to have' < rašû (DUL 748, CAD R 193), ${ }^{103} s b$ -

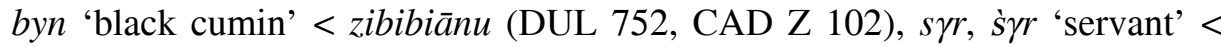
șuhāru (DUL 755, CAD Ș 231), ${ }^{104}$ šmt 'reddish shade' < sāmtu (DUL 831, CAD

responsible for a deeper, chronologically and geographically more intensive interaction, which could affect even the most basic lexical strata.

${ }^{98}$ Penetrating remarks on individual lexemes by such leading figures of Ugaritological, Semitological and Assyriological scholarship as A. Goetze, W. Moran, J. Huehnergard and D. Pardee (v. references below) are not sufficient to replace a systematic treatment of this fascinating subject.

${ }^{99}$ The references to Watson's studies are conveniently summarized in WATSON 2006:727728.

100 This is clear from the distribution chart in WATSON 1999:793.

${ }^{101}$ Persuasive arguments in favor of this etymology can be found in HUEHNERGARD 1987:144145.

${ }^{102}$ In the combination $r b$ nkšy 'chief accountant' (6:66:3-4) v. SANMARTín 1995:459-460.

${ }^{103}$ For the relevant passage $(2.41: 14-15)$ and the expression hwt yrš v. MÁrQuEz RowE 1992:152-153.

${ }^{104}$ Akkadian origin advocated in TROPPER 2000:46 seems likely in view of the fact that PS * syr '(to be) small' is well attested in Ugaritic in its original form (DUL 780), although it remains unclear why Akk. $h$ and $s$ should have shifted to $\gamma$ and $s(\dot{s})$ in Ugaritic. The former correspondence could probably be explained by the speaker's awareness of the etymological relationship between șuhāru and $s \gamma r$ (an etymologically motivated contamination, as in Biblical Aramaic hălāk < Akkadian $i l k u$ ). The latter can only be accounted for by some sort of phonetic difference between

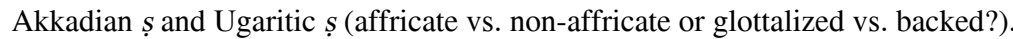


S 121), ššmn 'sesam' < šamaššammū (DUL 847, CAD Š 1 301), št 'measure of capacity' < sūtu (DUL 831, CAD S 420). ${ }^{10}$

Is it possible to subsume under this group some of the terms from our list of exclusive Ugaritic-Akkadian lexical isoglosses? Hardly so. On the one hand, the relevant words are almost never connected with realia: most of the concepts involved, even if not very fundamental, are universally known and could have been easily expressed by native words. On the other hand, the majority of their attestations come from myths and epics, where all types of loanwords (and especially Akkadisms) are empirically known to be rare.

As common sense nevertheless suggests, the probability of an Akkadian origin for some of the lexemes from our list is rather high. Here belong 'ugr 'field' (No. 1), 'ušr 'penis' (No. 4), ${ }^{107} h w t$ 'word' (No. 7), ${ }^{108}$ hpr 'ration' (No. 8), hrn 'gang, caravan' (No. 9), ht 'sceptre, rod' (No. 10), krd 'hero' (No. 14), ngr 'herald' (No. 18), ${ }^{109} \mathrm{nmrt}$ 'splendour' (No. 19), ${ }^{110} \mathrm{phd}$ 'a yearling lamb' (No. 21), $s^{\prime}$ in 'edge, hem' (No. 22), ${ }^{111}$ tmn 'foundation' (No. 24), trbṣ 'yard' (No. 25), ${ }^{112}$ trh 'to get married' (No. 26). ${ }^{113}$ In some cases this attribution may look subjective, but more often the reasons behind it are quite transparent: a highly specific non-basic meaning ('ration', 'caravan', 'sceptre', 'hero', 'herald', 'splendour',

\footnotetext{
${ }^{105}$ It may be not superfluous to list here a few other lexemes qualified as Akkadisms in DUL, but in fact more or less uncertain both philologically and etymologically: $m m$ 'winter' < mammû (DUL 559), msg 'skin, leather' < mašku (DUL 581), rpš 'open country' - rapšu (DUL 744), škm 'one who brays, donkey' < šăgimu (DUL 815), šml 'commercial agent' < šamallû (DUL 825).

${ }^{106} \mathrm{I}$ am convinced that the allegedly broad presence of Hurrian, Hittite and Egyptian loanwords in epics and myths as reflected in the chart in WATSON 1999:793 is largely due to uncritical selection. This is not to pretend that Akkadisms are altogether missing from epics and myths, but fully reliable examples (like $\check{s} d<\check{s i} d d u$ 'a measure of lengh', DUL 809, CAD Š 2403 ) are indeed extremely few.
}

${ }^{107}$ Explicitly qualified as a cognate in PARDEE 1997:289.

${ }^{108}$ Apparently treated as a cognate in GoETZE 1947:245.

${ }^{109}$ Cf. SASSMANSHAusen 1995:93: “obdas Vorkommen des nägiruin Ugaritaufmesopotamischen Einfluß zurückführen ist oder ob die Wurzel $n g r$ in diesem Bedeutungszusammenhang vielmehr im Ugaritischen altererbt ist, läßt sich derzeit nicht entscheiden".

${ }^{110}$ An Akkadism according to PARDEE 1988:115.

${ }^{111}$ According to MoRAn 1983, "perhaps an old loanword from Akk. before the loss in the latter of the aleph, or perhaps both going back to a common source and the textile vocabulary of the third millennium B.C.?". The possibility of an Akkadian loanword in Ugaritic is emphatically rejected in Durand 2009:95.

112 According to HuEHNERGARD (1987:176), "whether Ugar. /tarbașu/ is native to the language, or a loan from Akk., cannot be determined" (cf. KüHNE 1974:159). Huehnergard is right to observe that later tarbāṣ u was indeed borrowed into Aramaic (KaUfman 1974:107).

${ }^{113}$ Probably an Akkadism according to GoETze 1947:241-242. 
'foundation', even 'word'); a peculiar phonological ('ušr, nmrt) or morphological (trbss) shape; a more or less feasible possibility of an eventual Sumerian origin ('ugr 'field', $n g r$ 'herald', tmn 'foundation').

Summing up: some Ugaritic lexemes look like Akkadisms but, by their semantic and/or distributional properties, differ greatly from generally acknowledged, ${ }^{114}$ "normal" Akkadian loanwords. In my opinion, a plausible solution of this paradox is to be sought in the chronological dimension of the borrowing process. Within such an approach, those Akkadian loanwords which denote specific realia in economic and administrative contexts are to be treated as recent borrowings roughly contemporary with the documents in which they are attested. This chronological stratum is opposed to another, considerably more ancient layer of Akkadisms to which most of the terms treated in the preceding paragraph can be attributed. An early date of borrowing can convincingly account for the broad attestation of the terms in question (notably, their presence in the most archaic monuments of Ugaritic literature) and, importantly, for their archaic phonological shape: evidently enough, such lexemes as $h w t$ 'word', $h p r$ 'ration' or s'in 'hem' could only be borrowed from very ancient, pre-OB varieties of Akkadian. That such early loanwords are indeed conceivable is clearly shown by $h k l$ 'palace' (and its WS cognates), evidently borrowed from a third millennium proto-form *haykal rather than from the standard Akkadian ekallu.

No less interesting is the geographic dimension of the problem. In order to account for such deeply rooted lexical Akkadisms, a notoriously close interaction between (proto-)Akkadian and (proto-)Ugaritic is to be assumed. Now, it may be doubted that "classical", core Mesopotamian Akkadian — with all its cultural prestige - could be responsible for such a marked lexical influence. Could we rather attribute this influence wider East Semitic linguistic (notably, lexical) presence in Syria in early periods?

\section{References}

Aartun 1968 - K. Aartun. Beiträge zum ugaritischen Lexikon. WdO 4:278-299.

Aistleitner 1963 - J. Aistleitner. Wörterbuch der ugaritischen Sprache. Berlin.

Albright 1954 - W. F. Albright. Northwest-Semitic Names in a List of Egyptian Slaves from the Eighteenth Century B. C. JAOS 74:222-233.

Albright 1958 - W. F. Albright. Specimens of Late Ugaritic Prose. BASOR 150:36-38.

al-Selwi 1987 - I. al-Selwi. Jemenitische Wörter in den Werken von al-Hamdān̄̄ und Našwān und ihre Parallelen in den semitischen Sprachen. Berlin.

${ }^{114}$ Inter alia, explicitly qualified as such by the authors of DUL — an admittedly impressionistic but, in practice, highly suggestive criterion. 
Artzi 1969 - P. Artzi. On the Cuneiform Background of the Northwest-Semitic Form of the Word $b r d l, b(a) r z(e) l$ 'Iron'. JNES 28:268-270.

Avanzini 2004 - A. Avanzini. Corpus of South Arabian Inscriptions. I-III. Qatabanic, Marginal Qatabanic, Awsanite Inscriptions. Pisa.

Barr 1973 - J. Barr. Ugaritic and Hebrew "ŠBM"? JSS 18:17-39.

Bauer 1914 - H. Bauer. Die Etymologie von Adam und Verwandtes. ZA 28:310-311.

Bauer-Leander 1927 - H. Bauer, P. Leander. Historische Grammatik der hebräischen Sprache. Halle.

Behnstedt 1992 - P. Behnstedt. Die nordjemenitischen Dialekte (Glossar). Buchstaben Alif - Dal. Wiesbaden.

Ben-Hayyim 2000 - Z. Ben-Hayyim. A Grammar of Samaritan Hebrew. Winona Lake.

Blau 1957 - J. Blau. Über homonyme und angeblich homonyme Wurzeln II. VT 7: 98-102.

Blau 1977 - J. Blau. 'Weak' Phonetic Change and the Hebrew śîn. HAR 1:67-119.

Blau 1978 - J. Blau. Hebrew and North West Semitic: Reflections on the Classification of Semitic Languages. HAR 2:21-44.

Bonechi 1997 - M. Bonechi. Lexique et idéologie royale à l'époque proto-syrienne. MARI 8:477-535.

Bordreuil 1991 - P. Bordreuil. La mention du mois d'adaru dans une lettre du roi de Tyr au roi d'Ougarit (RS 18.59 1.14). Semitica 40:28-30.

Bordreuil-Pardee 1991 - P. Bordreuil, D. Pardee. Les textes en cunéiformes alphabétiques. Une bibliothèque au sud de la ville (RSOu 7). Paris. Pp. 139-174.

Bordreuil-Pardee 2001 - P. Bordreuil, D. Pardee. Textes alphabétiques en ougaritique. Études ougaritiques. I. Travaux 1985-1995 (RSOu 14). Paris. Pp. 341-392, 411-414.

Bordreuil-Pardee 2004 - P. Bordreuil, D. Pardee. Manuel d'ougaritique. Vol. II. Choix des textes. Glossaire. Paris.

Brockelmann 1927 - C. Brockelmann. Semitische Reimwortbildungen. ZS 5:6-38.

Brockelmann 1950 - C. Brockelmann. Abessinische Studien. Berlin.

Buck 1949 - C. Buck. A Dictionary of Selected Synonyms in the Principal Indo-European Languages. Chicago-London.

Bulakh 2005 - M. Bulakh. Cvetooboznačenie semitskih jazykov v etimologičeskom aspekte. Unpublished doctoral dissertation, Russian State University for the Humanities, Moscow.

Bulakh 2006 - M. Bulakh. Basic Color Terms of Biblical Hebrew in Diachronic Aspect. BuB 3:182- 216.

Cazelles 1969 - H. Cazelles. myn = espèce, race ou ressemblance? École des langues orientales anciennes de l'Institut catholique de Paris: Mémorial du cinquantenaire, 1914 1964. Paris. Pp. 105-108.

Civil 2007 - M. Civil. Early Semitic Loanwords in Sumerian. Studies Presented to Robert D. Biggs. Chicago. Pp. 11-33.

Cohen-Sivan 1983 - C. Cohen, D. Sivan. The Ugaritic Hippiatric Texts. New Haven. 
Cooke 1936 - G. Cooke. A Critical and Exegetical Commentary on the Book of Ezekiel. Edinburgh.

Dahood 1963 - M. Dahood. Ugaritic-Hebrew Lexicography I. Biblica 44:289-303.

del Olmo Lete 1981 - G. del Olmo Lete. Mitos y leyendas de Canaán según la tradición de Ugarit. Madrid-Valencia.

del Olmo Lete 1986 - G. del Olmo Lete. Fenicio y Ugarítico: correlación lingüística. AuOr. 4:31-49.

del Olmo Lete 2001 - G. del Olmo Lete. Origen y decadenica de Dagán. ...Ir a buscar leña. Estudios dedicados al prof. Jesús López. Barcelona. Pp. 85-90.

del Olmo Lete 2004 - G. del Olmo Lete. Canaanite Religion according to the Liturgical Texts of Ugarit. Winona Lake.

de Moor 1971 - J. de Moor. The Seasonal Pattern in the Ugaritic Myth of Ba lu. NeukirchenVluyn.

de Moor 1980 - J. de Moor. The Anatomy of the Back. UF 12:425-426.

Diakonoff-Kogan 2001 - I. Diakonoff, L. Kogan. Semitic Terms of Kinship and Social Sphere. Von Ägypten zum Tschadsee - eine linguistische Reise durch Afrika: Festschrift für Herrmann Jungraithmayr zum 65. Geburtstag. Würzburg. Pp. 147-158.

Dietrich-Loretz 1978 - M. Dietrich, O. Loretz. Ug. tmn 'Gestalt'. UF 10:432-433.

Dijkstra 1975 - M. Dijkstra. Does Occur the Verb $h b t$ in CTA 4:III.21? UF 7:563-565.

Durand 1998 - J.-M. Les documents épistolaires du palais de Mari. T. II. Paris.

Durand 2000 - J.-M. Durand. Les documents épistolaires du palais de Mari. T. III. Paris.

Durand 2009 - J.-M. Durand. La nomenclature des habits et des textiles dans les textes de Mari. Paris.

Edzard 1981 - D. O. Edzard. Review of CAD N. ZA 71:280-288.

Edzard 1994 - D. O. Edzard. namir 'er ist glänzend'. ASJ 16:1-14.

Emerton 1977 - J. Emerton. The Etymology of hištaḥawāh. OTS 20:41-55.

Faber 1991 - A. Faber. The Diachronic Relationship between Negative and Interrogative Markers in Semitic. Semitic Studies in Honor of Wolf Leslau on the Occasion of His Eighty-fifth Birthday. Wiesbaden. Pp. 411-429.

Fabry 1997 - H.-J. Fabry. mîn. TDOT 7:288-291.

Farber 1989 - W. Farber. Schlaf, Kindchen, Schlaf! Mesopotamische Baby-Beschwörungen und-Rituale. Winona Lake.

Fick 1909 - A. Fick. Wörterbuch der indogermanischen Sprachen. III. Wortschatz der germanischen Spracheinheit. Göttingen.

Fischer 2002 - W. Fischer. A Grammar of Classical Arabic. New Haven-London.

Fitzmyer 1995 - J. Fitzmyer. The Aramaic Inscriptions of Sefire. Roma.

Ford 2002a - J. Ford. The New Ugaritic Incantation against Sorcery RS 1992.2014. UF 34:119-152.

Ford 2002b - J. Ford. The Ugaritic Incantation against Sorcery RIH 78/20 (KTU² 1.169). UF 34:153-211.

Friedrich-Röllig 1999 - J. Friedrich, W. Röllig. Phönizisch-Punische Grammatik. Roma. 
Fronzaroli 1965 - P. Fronzaroli. Studi sul lessico comune semitico. III. ANLR VIII/XX/34:135-150.

Fronzaroli 1966-1967 - P. Fronzaroli. Il mare e i corsi d'acqua nel lessico comune semitico. Bollettino dell'Atlante linguistico mediterraneo 8-9:205-213.

Fronzaroli, 1968 - P. Fronzaroli. Studi sul lessico comune semitico. V. ANLR VIII/XXIII/712:267-303.

Fronzaroli 1969 - P. Fronzaroli. Studi sul lessico comune semitico. VI. ANLR VIII/XXIV/712:1-36.

Fronzaroli 1971 - P. Fronzaroli. Studi sul lessico comune semitico. VII. ANLR VIII/XXVI/7$12,603-643$.

Fronzaroli 1984 - P. Fronzaroli. Materiali per il lessico eblaita, 1. StEb. 7:145-190.

Garbini 1978 - G. Garbini. *parzōn 'iron' in the Song of Deborah? JSS 23:23-24.

Garbini 1984 - G. Garbini. Le lingue semitiche. Napoli.

George 2003 - A. George. The Babylonian Gilgamesh Epic. Oxford.

Gelb 1957 - I. J. Gelb. Glossary of Old Akkadian. Chicago.

Gertz 2006 - J. Gertz. tûš̂̀yâ. TDOT 15:647-650.

Gibson 1982 - J. Gibson. Textbook of Syrian Semitic Inscriptions. III. Phoenician Inscriptions Including Inscriptions in the Mixed Dialect of Arslan Tash. Oxford.

Ginsberg 1970 - H. L. Ginsberg. The Northwest Semitic Languages. The World History of Jewish People. Vol. II. Patriarchs. Rutgers. Pp. 102-124.

Ginsberg 1973 - H. L. Ginsberg. Ugaritico-Phoenicia. JANES 5:131-147.

Goetze 1947 - A. Goetze. Long or Short $a$ ? Or. 16:239-250.

Greenberg 1950 - J. Greenberg. The Patterning of Root Morphemes in Semitic. Word 6:162-181.

Greenfield 1958 - J. Greefnfield. Lexicographic Notes I. HUCA 29:203-228.

Greenfield 1959 - J. Greenfield. Lexicographic Notes II. HUCA 30:141-152.

Greenfield 1967 - J. Greenfield. Ugaritic Lexicographical Notes. JCS 21:89-93.

Greenfield 1969 - J. Greenfield. Amurrite, Ugaritic and Canaanite. Proceedings of the International Conference of Semitic Studies. Jerusalem. Pp. 92-101.

Gzella 2007 - H. Gzella. Some Penciled Notes on Ugaritic Lexicography. BiOr. 64:527-567.

Haldar 1964 - A. Haldar. The Position of Ugaritic among the Semitic Languages. BiOr. 21:266-276.

Harris 1939 - Z. Harris. Development of the Canaanite Dialects. New Haven.

Hasselbach 2005 - R. Hasselbach. Sargonic Akkadian. Wiesbaden.

Hasselbach-Huehnergard 2007 - R. Hasselbach, J. Huehnergard. Northwest Semitic Languages. Encyclopedia of Arabic Language and Linguistics 3:408-422.

Healey 1995 - J. Healey. Ugaritic and Arabic. Ugarit. Ein Ostmediterranes Kulturzentrum im Alten Orient. I. Ugarit und seine altorientalische Umwelt. Münster. Pp. 75-85.

Helck 1971 - W. Helck. Die Beziehungen Ägyptens zu Vorderasien im 3. und 2. Jahrtausend v. Chr. Wiesbaden.

Held 1959 - M. Held. mḥș/*mȟs in Ugaritic and Other Semitic Languages. JAOS 79:169-176. 
Heltzer 1982 - M. Heltzer. The Internal Organization of the Kingdom of Ugarit. Wiesbaden.

Heltzer 1999 - M. Heltzer. Again about the gt in Ugarit. UF 31:193-197.

Hillers-Cussini 1996 - D. Hillers, E. Cussini. Palmyrene Aramaic Texts. Baltimore.

Hoch 1994 - J. Hoch. Semitic Words in Egyptian Texts of the New Kingdom and Third Intermediate Period. Princeton.

Horowitz-Oshima 2006 - W. Horowitz, T. Oshima. Cuneiform in Canaan. Cuneiform Sources from the Land of Israel in Ancient Times. Jerusalem.

Hrozný 1913 - F. Hrozný. Das Getreide im alten Babylonien. Wien.

Huehnergard 1987 - J. Huehnergard. Ugaritic Vocabulary in Syllabic Transcription. Atlanta.

Huehnergard 1991a - J. Huehnergard. Further South Semitic cognates to the Akkadian lexicon. Semitic Studies in Honor of Wolf Leslau. Wiesbaden. Pp. 690-713.

Huehnergard 1991b - J. Huehnergard. Remarks on the Classification of Northwest Semitic Languages. The Balaam Text from Deir 'Alla Re-evaluated. Leiden. Pp. 282-293.

Huehnergard 2002 - J. Huehnergard. izuzzum and itūlum. Riches Hidden in Secret Places. Ancient Near Eastern Studies in Memory of Thorkild Jacobsen. Winona Lake. Pp. 161-185.

Huehnergard 2003 - J. Huehnergard. Akkadian ḩ and West Semitic *ḥ. Studia Semitica. Moscow. Pp. 102-119.

Huehnergard 2005 - J. Huehnergard. Features of Central Semitic. Biblical and Oriental Essays in Memory of William L. Moran. Roma. Pp. 155-203.

Huehnergard 2008 - J. Huehnergard. Ugaritic Vocabulary in Syllabic Transcription. Second edition. Winona Lake.

Hurwitz 1913 - S. Hurwitz. Root-Determinatives in Semitic Speech. New York.

Jackson 1982 - K. Jackson. The Ammonite Language of the Iron Age. Chico.

Jamme 1962 - A. Jamme. Sabaean Inscriptions from Maḥram Bilqîs (Mârib). Baltimore.

Jeffery 1938 - A. Jeffery. The Foreign Vocabulary of the Qur'ān. Baroda.

Kaufman 1974 - S. Kaufman. The Akkadian Influences on Aramaic. Chicago.

Kaye 1991 - A. Kaye. Does Ugaritic Go with Arabic in Semitic Genealogical Subclassification? Folia Orientalia 28:115-128.

Kienast 1994 - B. Kienast. Glossar zu den altakkadischen Königsinschriften. Stuttgart.

Koehler 1940 - L. Koehler. Hebräische Etymologien. JBL 59:35-40.

Kogan 2005 - L. Kogan. Lexicon of Old Aramaic Inscriptions and the Historical Unity of Aramaic. $B u B$ 2:513-566.

Kogan 2006a - L. Kogan. Lexical Evidence and the Genealogical Position of Ugaritic (I). BuB 3:429-488.

Kogan 2006b - L. Kogan. The Etymology of Israel (with an Appendix on Non-Hebrew Semitic Names among Hebrews in the Old Testament). BuB 3:237-255.

Kogan 2011 - L. Kogan. One More Cuneiform Attestation of *na' $r$ - 'boy, lad'. Forthcoming in a FS. 
Kogan-Korotaev 2003 - L. Kogan, A. Korotaev. Animals and Beyond. A New Work on Epigraphic South Arabian Realia. WZKM 93:95-118.

Kopf 1976 - L. Kopf. Studies in Hebrew and Arabic Lexicography. Jerusalem.

Kouwenberg 2008 - N. J. C. Kouwenberg. On the Old Assyrian Verb atawwum 'to speak' and Related Issues. Old Assyrian Studies in Memory of Paul Garelli. Leiden. Pp. 159173.

Krahmalkov 2000 - Ch. Krahmalkov. Phoenician-Punic Dictionary. Leuven.

Krebernik 1985 - M. Krebernik. Zur Entwicklung der Keilschrift im III. Jahrtausend anhand der Texte aus Ebla. AfO 32:53-59.

Krebernik 2006 - M. Krebernik. Some Questions Concerning Word Formation in Akkadian. The Akkadian Language in Its Semitic Context. Leiden. Pp. 84-95.

Kreuzer 1985 - S. Kreuzer. Zur Bedeutung und Etymologie von hišta ḥִ wāh/yštḥwy. VT 35:39-60.

Kühne 1974 - C. Kühne. Mit Glossenkeil markierte fremde Wörter in akkadischen Ugarittexten. UF 6:157-167.

Landberg 1920 - C. Landberg. Glossaire Datînois. Vol. 1. Leiden.

Landsberger 1967 - B. Landsberger. Akkadisch-Hebräische Wortgleichungen. Hebräische Wortforschung. Festschrift zum 80. Geburtstag von Walter Baumgartner. Leiden. Pp. 176-204.

Leslau 1956 - W. Leslau. Ethiopic and South Arabic Contributions to the Hebrew Lexicon. Berkeley.

Leslau 1969 - W. Leslau. The Negative Particle 'in in Arabic and 'on in Ethiopic. AION 29:137-145.

Levine-de Tarragon-Robertson 1997 - B. Levine, J.-M. de Tarragon, A. Robertson. The Patrons of the Ugaritic Dynasty (KTU 1.161). The Context of the Scripture. I. Canonical Compositions from the Biblical World. Leiden-New York-Köln. Pp. 357-358.

Lieberman 1977 - S. Lieberman. Sumerian Loanwords in Old Babylonian Akkadian. Missoula.

Lipiński 1970 - E. Lipiński. Banquet en l'honneur de Baal. UF 2:75-88.

Liverani 1964 - Elementi innovativi nell'ugaritico non letterario. ANLR VIII/XIX/1-2:173191.

Loewenstamm 1980 - S. Loewenstamm. Comparative Studies in Biblical and Ancient Orienal Literatures. Kevelaer-Neukirchen.

Loretz 1993 - O. Loretz. Ugaritisch-hebräisch h̆mr/ḥmr und msk(/mzg). UF 25:247-258.

Loretz 1995 - O. Loretz. Ugaritische Lexicographie. SEL 12:105-120.

Löw 1881 - I. Löw. Aramäische Pflanzennamen. Leipzig.

Maizel 1983 - S. Maizel. Puti razvitija kornevogo fonda semitskih jazykov. Moscow.

Márquez Rowe 1992 - I. Márquez Rowe. Akkadisms in Ugaritic Texts. KTU 2.41:14-22. AuOr. 10:152-154.

Marrassini 1971 - P. Marrassini. Formazione del lessico dell' edilizia militare nel semitico di Siria. Firenze. 
Michaut-Colombot 1997 - D. Michaut-Colombot. La gat de Gédéon, pressoir ou fief? UF 29:579-598.

Moran 1983 - W. Moran. Notes brèves. sūnu II. RA 77:93-94.

Moran 1992 - W. Moran. The Amarna Letters. Baltimore.

Moscati 1946 - S. Moscati. La radice semitica 'mr. Biblica 27:115-126.

Muchiki 1999 - Y. Muchiki. Egyptian Proper Names and Loanwords in North-West Semitic. Atlanta.

Müller 1995 - W. Müller. Beiträge aus dem Śḥeri zum etymologischen Teil des hebräischen Lexikons. Meilenstein. Festgabe für Herbert Donner. Wiesbaden. Pp. 143-153.

Nöldeke 1904 - T. Nöldeke. Beiträge zur semitischen Sprachwissenschaft. Straßburg.

Nöldeke 1910 - T. Nöldeke. Neue Beiträge zur semitischen Sprachwissenschaft. Straßburg.

Pardee 1978 - D. Pardee. yph 'witness' in Hebrew and Ugaritic. VT 28:204-213.

Pardee 1988 - D. Pardee. Les textes para-mythologiques de la 24e campagne (1961). Paris.

Pardee 1994 - D. Pardee. Will the Dragon Never Be Muzzled? UF 16:251-255.

Pardee 1997 - D. Pardee. Miscellaneous Ugaritic texts translated and commented in the section "West Semitic Canonical Compositions". The Context of Scripture. I. Canonical Compositions from the Biblical World. Leiden-New York-Köln.

Pardee 2000 - D. Pardee. Les textes rituels (RSOu 12). Paris.

Pardee 2002 - D. Pardee. Ugaritic Letters. The Context of the Scripture. III. Archival Documents from the Biblical World. Leiden-Boston-Köln. Pp. 87-116.

Pardee 2007 - D. Pardee. Preliminary Presentation of a New Ugaritic Song to 'Attartu (RIH 98/02). Ugarit at Seventy-Five. Winona Lake. Pp. 27-39.

Pirenne 1990 - J. Pirenne. Fouilles de Shabwa. I. Les témoins écrits de la région de Shabwa et l'histoire. Paris.

Poebel 1939 - A. Poebel. Studies in Akkadian Grammar. Chicago.

Pope 1947 - M. Pope. A Note on Ugaritic ndd-ydd. JCS 1:337-341.

Pope 1965 - M. Pope. Job (The Anchor Bible). New York.

Porten-Yardeni 1993 - B. Porten, A. Yardeni. Textbook of Aramaic Documents from Ancient Egypt. III. Literature, Accounts, Lists. Jerusalem.

Preuss 1980 - H. Preuss. hwwh; hishtach ${ }^{a} v a \bar{h}$. TDOT 4:248-256.

Rabin 1963 - Ch. Rabin. Hittite Words in Hebrew. Or. 113-139.

Rainey 1976 - A. Rainey. A Tri-lingual Cuneiform Fragment from Tel Aphek. Tel Aviv 3:137-140.

Rainey 1977 - A. Rainey. Verbal Usages in the Taanach Tablets. IOS 7:33-64.

Rainey 1978 - A. Rainey. El Amarna Tablets 359-379. Kevelaer-Neukirchen.

Rainey 1996 - A. Rainey. Canaanite in the Amarna Tablets. A Linguistic Analysis of the Mixed Dialect Used by the Scribes from Canaan. Leiden.

Rainey 1998 - A. Rainey. Egyptian Evidence for Semitic Linguistics. IOS 18:431-453.

Reiter 1997 - K. Reiter. Die Metalle im Alten Orient. Münster.

Renfroe 1992 - F. Renfroe. Arabic-Ugaritic Lexical Studies. Münster. 
Reuter 2006 - E. Reuter. šipḥ̂. TDOT 15:405-410.

Ribichini-Xella 1985 - S. Ribichini, P. Xella. La terminologia dei tessili nei testi di Ugarit. Roma.

Ritter 1990 - H. Ritter. Țūrōyo. C. Grammatik. Stuttgart.

Robin 1982 - Ch. Robin. Les hautes-terres du Nord-Yemen avant l'Islam. Istanbul.

Roth 1987 - M. Roth. Age at Marriage and the Household: A Study of Neo-Assyrian and Neo-Babylonian Forms. Comparative Studies in Society and History 29:715-747.

Rubio 1999 - G. Rubio. On the Alleged "Pre-Sumerian Substratum”. JCS 51:1-16.

Rundgren 1963 - F. Rundgren. Hebräisch bäsäar "Golderz” und 'āmar "sagen”. Zwei Egymologien. Or. 32:178-183.

Ryckmans 1973 - J. Ryckmans. Un rite d'istisqâ' au temple sabéen de Mârib. Annuaire de l'Institut de Philologie et d'Histoire Orientales et Slaves 20:379-388.

Sanmartín 1973 - J. Sanmartín. Semantisches über 'MR/“Sehen” und 'MR/“Sagen” im Ugaritischen. UF 5:263-270.

Sanmartín 1977 - J. Sanmartín. Semantisches über Ug. ADN. UF 9:269-272.

Sanmartín 1978 - J. Sanmartín. Glossen zum ugaritischen Lexicon (II). UF 10:350-356.

Sanmartín 1979 - J. Sanmartín. Glossen zum ugaritischen Lexicon (III). UF 11:723-728.

Sanmartín 1989 - J. Sanmartín. Glossen zum ugaritischen Lexicon (IV). UF 12:335-339.

Sanmartín 1991 - J. Sanmartín. Isoglosas morfoléxicas eblaítico-ugaríticas: la trampa lexicográfica. AuOr. 9:165-217.

Sanmartín 1995 - J. Sanmartín. Zur Schreibpraxis der ugaritischen Siegelschneider: die Siegellegende KTU 6.66. UF 27:455-465.

Sassmanshausen 1995 - L. Sassmanshausen. Funktion und Stellung der Herolde (n i g i r / nāgiru) im alten Orient. BaM 26:85-194.

Schloen 2001 - D. Schloen. The House of the Father as Fact and Symbol. Winona Lake.

Schmidt 1978 - W. Schmidt. dābhar; dābhār. TDOT 3:84-125.

Schwemer 2001 - D. Schwemer. Die Wettergottgestalten. Wiesbaden.

Segert 1969 - S. Segert. Ugaritisch und Aramäisch. Studia semitica Ioanni Bakoš dicata. Bratislava. Pp. 215-226.

Segert 1984 - S. Segert. A Basic Grammar of the Ugaritic Language. Berkeley.

Singer 1999 - I. Singer. A Political History of Ugarit. Handbook of Ugaritic Studies. LeidenBoston-Köln. Pp. 603-733.

Sjöberg 1996 - ̊̊. Sjöberg. Eve and the Chamaeleon. In the Shelter of Elyon. FS G. Ahlström. Sheffield. Pp. 217-225.

Smith 1994 - M. Smith. The Ugaritic Baal Cycle. I. Introduction with Text, Translation and Commentary of KTU 1.1-1.2. Leiden.

Sommerfeld 1999 - W. Sommerfeld. Die Texte der Akkade-Zeit. 1. Das Dijala-Gebiet: Tutub. Münster, 1999.

Sommerfeld 2006 - W. Sommerfeld. Die ältesten semitischen Sprachzeugnisse - eine kritische Bestandsaufnahme. The Akkadian Language in Its Semitic Context. Leiden. Pp. 30-75. 
Stein 2003 - P. Stein. Ungersuchungen zur Phonologie und Morphologie des Sabäischen. Rahden.

Steiner 1977 - R. Steiner. The Case for Fricative-Laterals in Proto-Semitic. New Haven.

Steiner 2003 - G. Steiner. Akkadische Lexeme im Sumerischen. Semitic and Assyriological Studies Presented to Pelio Fronzaroli. Wiesbaden. Pp. 630-647.

Stol 2000 - M. Stol. Birth in Babylonia and the Bible. Its Mediterranean Setting. Groningen.

Streck 2000 - M. Streck. Das amurritsche Onomastikon der altbabylonischen Zeit. Münster.

Tomback 1978 - R. Tomback. A Comparative Semitic Lexicon of the Phoenician and Punic Languages. Missoula.

Tropper 1990 - J. Tropper. Der ugaritische Kausativstamm und die Kausativbildungen des Semitischen. Münster.

Tropper 1993 - J. Tropper. Die Inschriften von Zincirli. Münster.

Tropper 1994 - J. Tropper. Is Ugaritic a Canaanite Language? Ugarit and the Bible. Münster. Pp. 343-353.

Tropper 1995a - J. Tropper. Die sieben Frauen des Königs Keret. UF 27:529-532.

Tropper 1995b - J. Tropper. Akkadisch nuhbutu und die Repräsentation des Phonems /ḥ/ im Akkadischen. ZA 85:58-66.

Tropper 1996 - J. Tropper. Auch Götter haben Angst. AuOr. 14:136-139.

Tropper 1997 - J. Tropper. Beiträge zur ugaritischen Lexikographie. UF 29:661-668.

Tropper 2000 - J. Tropper. Ugaritische Grammatik. Münster.

Tropper 2003 - J. Tropper. Kanaanäische Lehnwörter im Ugaritischen. UF 35:663-671.

Tropper-Hayajneh 2003 - J. Tropper, H. Hayajneh. El, der scharfsinnige und verständige Gott. Or. 72:159-182.

Tropper-Verreet 1988 - J. Tropper, E. Verreet. Ugaritisch $n d y, h d y, n d d$ und $d(w) d$. UF 20:339-350.

Vanoni 2004a - G. Vanoni. śîm. TDOT 14:89-112.

Vanoni 2004b - G. Vanoni. šît. TDOT 14:646-659.

van Soldt 1991 - W. van Soldt. Studies in the Akkadian of Ugarit. Dating and Grammar. Neukirchen-Vluyn.

van Sodlt 1997 - W. van Soldt. Amarna $u p s u$ = Ugaritic 'ps, "boundary stone". NABU 1997/90.

van Soldt 2005 - W. van Soldt. The Topography of the City-State of Ugarit. Münster.

Veenhof 1986 - K. Veenhof. Two Akkadian Auxiliary Verbs. Scripta Signa Vocis: Studies about Scripts, Scriptures, Scribes and Languages in the Near East, presented to J. H. Hospers. Groningen. Pp. 235-250.

Vergote 1945 - J. Vergote. Phonétique historique de l'égyptien. Louvain.

von Soden 1952 - W. von Soden. Unregelmässige Verben im Akkadischen. ZA 50:162181.

von Soden 1969 - W. von Soden. Zur Herkunft von hebr. ebjôn "arm”. MIO 15:322-326. 
von Soden-Röllig 1991 - W. von Soden, W. Röllig. Das akkadische Syllabar. Roma. Waschke 2006 - E.-J. Waschke. təmūnā. TDOT 15:687-690.

Wagner 1966 - M. Wagner. Die lexikalischen und grammatikalischen Aramaismen im alttestamentlichen Hebräisch. Berlin.

Watson 1995 - W. Watson. Ugaritic Lexical Studies in Perspective. SEL 12:217-228.

Watson 1999 - W. Watson. Non-Semitic Words in the Ugaritic Lexicon (4). UF 31:785799.

Watson 2002 - W. Watson. Terms for "rain" in Ugaritic. Ex Mesopotamia et Syria Lux (FS M. Dietrich). Münster. Pp. 795-801.

Watson 2006 - W. Watson. Non-Semitic Words in the Ugaritic Lexicon (6). UF 38:717728.

Weippert 1974 - M. Weippert. AD.DA.A.NI in den Briefen des Abduheba von Jerusalem an den Pharao. UF 6:415-419.

Woodhouse 2003 - R. Woodhouse. The Biblical Shibboleth Story in the Light of Late Egyptian Perceptions of Semitic Sibilants: Reconciling Divergent Views. JAOS 123:271-289.

Xella 1982 - P. Xella. Die Ausrüstung eines Kanaanäischen Schiffes (KTU 4.689). WO 13:31-5.

Yahuda 1903 - A. Yahuda. Hapax Legomena im Alten Testament. JQR 15:698-714.

Zaborski 1971 - A. Zaborski. Biconsonantal Verbal Roots in Semitic. Prace Językoznawcze 35: 51-98.

Zobel 1998 - H.-J. Zobel. mātāar; gešem; zerem. TDOT 8:250-265.

\section{Abbreviations of lexicographic and grammatical tools}

AED - T. L. Kane. Amharic-English Dictionary. Wiesbaden, 1990.

AHw. - W. von Soden. Akkadisches Handwörterbuch. Wiesbaden, 1965-1981.

BDB - F. Brown, S. R. Driver, Ch. A. Briggs. A Hebrew and Aramaic Lexicon of the Old Testament. Oxford, 1951.

Biella - J. C. Biella. Dictionary of Old South Arabic. Chico, 1982.

BK - A. de Biberstein Kazimirski. Dictionnaire Arabe-Français. Paris, 1860.

CAD - The Assyrian Dictionary of the Oriental Institute, the University of Chicago. Chicago, 1956-.

CDG - W. Leslau. Comparative Dictionary of Ge'ez. (Classical Ethiopic). Wiesbaden, 1987.

DCH - D. Clines. The Dictionary of Classical Hebrew. Sheffield, 1993.

DJA - M. Sokoloff. A Dictionary of Judaean Aramaic. Ramat-Gan, 2003.

DJBA - M. Sokoloff. A Dictionary of Jewish Babylonian Aramaic. Ramat-Gan-Baltimore, 2002. 
DJPA - M. Sokoloff. A Dictionary of Jewish Palestinian Aramaic. Ramat-Gan-Baltimore, 2002.

DNWSI - J. Hoftijzer, K. Jongeling. Dictionary of the North-West Semitic Inscriptions. Leiden-New York-Köln, 1995.

DRS - D. Cohen et al. Dictionnaire des racines sémitiques. Paris-La Haye, 1970-.

DUL - G. del Olmo Lete, J.Sanmartín. A Dictionary of the Ugaritic Language in the Alphabetic Tradition. Leiden-Boston, 2003.

EDG - W. Leslau. Etymological Dictionary of Gurage (Ethiopic). Vol. III. Wiesbaden, 1979.

EDH - W. Leslau. Etymological Dictionary of Harari. Berkeley-Los Angeles, 1963.

Friedrich - J. Friedrich. Hethitisches Wörterbuch. Heidelberg, 1952.

GAG - W. von Soden. Grundriß der akkadischen Grammatik. Roma, 1995.

HALOT - L. Koehler, W. Baumgartner, J. J. Stamm. The Hebrew and Aramaic Lexicon of the Old Testament. Leiden-New York-Köln, 1994-2000.

Ja. - M. Jastrow. A Dictionary of the Targumim, the Talmud Babli and Yerushalmi, and the Midrashic Literature. New York, 1996.

JL - T. M. Johnstone. Jibbāli Lexicon. Oxford, 1981.

LA - Ibn Mandūr. Lisānu l- 'arab. Bayrūt, 1990.

Lane - E. W. Lane. Arabic-English Lexicon. London, 1867.

Laroche - E. Laroche. Glossaire de la langue hourrite. Paris, 1980.

LIQ - S. D. Ricks. Lexicon of Inscriptional Qatabanian. Roma, 1989.

LLA - A. Dillmann. Lexicon linguae aethiopicae. Leipzig, 1865.

LM - M. Arbach. Le madābien: lexique, onomastique et grammaire d'une langue de l'Arabie méridionale préislamique. T. I. Lexique mādbien. Aix-en-Provence, 1993.

LS - W. Leslau. Lexique Soqotri (Sudarabique moderne) avec comparaisons et explications étymologiques. Paris, 1938.

LSyr. - C. Brockelmann. Lexicon Syriacum. Halle, 1928.

MD - E. S. Drower, R. Macuch. A Mandaic Dictionary. Oxford, 1963.

ML - T. M. Johnstone. Mehri Lexicon. London, 1987.

Piamenta - M. Piamenta. Dictionary of Post-Classical Yemeni Arabic. Leiden, 1990.

PS - R. Payne Smith. Thesaurus Syriacus. Oxford, 1879-1901.

PS Supplement - J. P. Margoliouth. Supplement to the Thesaurus Syriacus of R. Payne Smith. Oxford, 1927.

PSD - The Sumerian Dictionary of the University Museum of the University of Pennsylvania. Philadelphia, 1984-.

SD - A. F. L. Beeston, M. A. Ghul, W. W. Müller, J. Ryckmans. Sabaic Dictionary (EnglishFrench-Arabic). Louvain-la-Neuve, 1982.

SED I - A. Militarev, L. Kogan. Semitic Etymological Dictionary. Vol. I. Anatomy of Man and Animals. Münster, 2000. 
SED II - A. Militarev, L. Kogan. Semitic Etymological Dictionary. Vol. II. Animal Names.

Münster, 2005.

SRJa - Slovar' russkogo jazyka XI-XVII vv. Moscow, 1975-.

TA - az-Zabīdī. Tāj al-'arūs. Kuwayt, 1965-2001.

TED - T. L. Kane. Tigrinya-English Dictionary. Springfield, 2000.

Wb. - A. Erman, H. Grapow. Ägyptisches Handwörterbuch. Berlin, 1921.

WKAS - M. Ullmann. Wörterbuch der klassischen arabischen Sprache. Wiesbaden, 1957-.

Wb. - A. Erman, H. Grapow. Wörterbuch der ägyptischen Sprache. Berlin, 1926-1963.

WH - A. Walde, J. Hoffmann. Lateinisches etymologisches Wörterbuch. Heidelberg, 1938.

WTS - E. Littmann, M. Höfner. Wörterbuch der Tigre-Sprache. Tigre-deutsch-englisch. Wiesbaden, 1956.

\section{Abbreviations of language names}

Akk. - Akkadian, Amh. - Amharic, Amm. - Ammonite, Arb. - Arabic, Arm. - Aramaic, CC - Common Canaanite, Cha. - Chaha, CS - Central Semitic, EA - Old Canaanite forms in the el-Amarna tablets, Eg.-syll. - syllabic Egyptian renderings of Canaanite lexemes, End. - Endegeň, Enm. - Ennemor, ES - Ethiopian Semitic, ESA - Epigraphic South Arabian, Gez. - Geez, Gyt. - Gyeto, Har. - Harari, Hbr. - Hebrew (pB. - postBiblical), Hdr. - Hadramitic, Hit. - Hittite, Hur. - Hurrian, JA - Jewish Aramaic (unspecified), JBA - Jewish Babylonian Aramaic, JdA - Judaean Aramaic, Jib. - Jibbali, JPA - Jewish Palestinian Aramaic, Mhr. - Mehri, Min. - Minaean, Mnd. - Mandaic, Moab. - Moabite, MSA - Modern South Arabian, Muh. - Muher, Nab. - Nabatean, NWS - North-West Semitic, OA - Old Assyrian, OB - Old Babylonian, Off. Arm. Official Aramaic, PCS - proto-Central Semitic, Pho. - Phoenician, PIE - Proto-IndoEuropean, Plm. - Palmyrean, PS - Proto-Semitic, PWS - Proto-West Semitic, Qat. Qatabanian, Sab. - Sabaic, Sel. - Selti, Sod. - Soddo, Soq. - Soqotri, Sum. - Sumerian, Syr. - Syriac, Tgr. - Tigre, Tna. - Tigrinya, Ugr. - Ugaritic, Wol. - Wolane, WS - West Semitic, Zwy. - Zway.

Recibido: 30/06/2009

Aceptado: 20/02/2010 